Article

\title{
Discovery of Novel Andrographolide Derivatives as Antiviral Inhibitors against Human Enterovirus A71
}

\author{
Jie Kai Tan ${ }^{1,+}\left(\mathbb{D}\right.$, Ran Chen ${ }^{2,+}$, Regina Ching Hua Lee ${ }^{1}$, Feng $\mathrm{Li}^{2}{ }^{2}$, Kun Dai ${ }^{2}$, Guo-Chun Zhou ${ }^{2, *}$ \\ and Justin Jang Hann Chu $1,3,4, * \mathbb{1}$
}

Citation: Tan, J.K.; Chen, R.; Lee, R.C.H.; Li, F.; Dai, K.; Zhou, G.-C.; Chu, J.J.H. Discovery of Novel Andrographolide Derivatives as Antiviral Inhibitors against Human Enterovirus A71. Pharmaceuticals 2022, 15, 115. https://doi.org/ $10.3390 /$ ph15020115

Academic Editor: Daniela De Vita

Received: 20 December 2021

Accepted: 17 January 2022

Published: 18 January 2022

Publisher's Note: MDPI stays neutral with regard to jurisdictional claims in published maps and institutional affiliations.

Copyright: (C) 2022 by the authors. Licensee MDPI, Basel, Switzerland. This article is an open access article distributed under the terms and conditions of the Creative Commons Attribution (CC BY) license (https:// creativecommons.org/licenses/by/ $4.0 /)$.
1 Laboratory of Molecular RNA Virology and Antiviral Strategies, Department of Microbiology and Immunology, Yong Loo Lin School of Medicine, National University of Singapore, Singapore 117545, Singapore; e0031885@u.nus.edu (J.K.T.); miclch@nus.edu.sg (R.C.H.L.)

2 School of Pharmaceutical Sciences, Nanjing Tech University, Nanjing 211816, China; 202162118026@njtech.edu.cn (R.C.); fengli9203@163.com (F.L.); daikun@renfu.com.cn (K.D.)

3 Infectious Disease Translational Research Programme, Yong Loo Lin School of Medicine, National University of Singapore, Singapore 117597, Singapore

4 Collaborative and Translation Unit for HFMD, Institute of Molecular and Cell Biology, Agency for Science, Technology and Research, Singapore 138673, Singapore

* Correspondence: gczhou@njtech.edu.cn (G.-C.Z.); miccjh@nus.edu.sg (J.J.H.C.)

+ These authors contributed equally to this work.

\begin{abstract}
Hand-foot-and-mouth disease (HFMD) caused by human enterovirus A71 (EV-A71) infection has been associated with severe neurological complications. With the lack of an internationally approved antiviral, coupled with a surge in outbreaks globally, EV-A71 has emerged as a neurotropic virus of high clinical importance. Andrographolide has many pharmacological effects including antiviral activity and its derivative, andrographolide sulfonate, has been used in China clinically to treat EV-A71 infections. This study sought to identify novel andrographolide derivatives as EV-A71 inhibitors and elucidate their antiviral mode of action. Using an immunofluorescence-based phenotypic screen, we identified novel EV-A71 inhibitors from a 344-compound library of andrographolide derivatives and validated them with viral plaque assays. Among these hits, ZAF-47, a quinolinoxyandrographolide, was selected for downstream mechanistic studies. It was found that ZAF-47 acts on EV-A71 post-entry stages and inhibits EV-A71 protein expression. Subsequent luciferase studies confirm that ZAF-47 targets EV-A71 genome RNA replication specifically. Unsuccessful attempts in generating resistant mutants led us to believe a host factor is likely to be involved which coincide with the finding that ZAF-47 exhibits broad-spectrum antiviral activity against other enteroviruses (CV-A16, CV-A6, Echo7, CV-B5, CV-A24 and EV-D68). Furthermore, ZAF-46 and ZAF-47, hits from the screen, were derivatives of the same series containing quinolinoxy and olefin modifications, suggesting that an andrographolide scaffold mounted with these unique moieties could be a potential anti-EV-A71/HFMD strategy.
\end{abstract}

Keywords: human enterovirus A71; andrographolide; quinolinoxy; olefin; viral RNA replication; host-targeting; broad-spectrum anti-enterovirus agent

\section{Introduction}

Andrographis paniculata (Burm.f.) Nees (family: Acanthaceae), also known as the "King of Bitters", is a medicinal plant native to India and Sri Lanka and widely distributed in tropical and subtropical regions such as Southeast Asia and China [1]. It is extensively cultivated due to its high medicinal value which includes anti-atherosclerotic, antidiarrheal, antihyperglycemic, anti-inflammatory, antimicrobial, antioxidant, antiplatelet aggregation, choleretic, hepatoprotective and hypotensive activities [2,3]. Among the many constituents of diterpenoids, flavonoids and polyphenols contributing to its pharmacology, andrographolide (1) stands out as the most abundant and biologically active component [1,3]. 
Andrographolide is anticancer, anti-inflammatory, antibacterial, immunomodulatory [2] but more importantly, antiviral [4]. It is reported to be effective against chikungunya virus (CHIKV) [5], dengue virus (DENV) [6,7], Epstein-Barr virus (EBV) [8], influenza A virus (IAV) [9], hepatitis B virus (HBV) [10], hepatitis C virus (HCV) [11], human immunodeficiency virus (HIV) [12,13], herpes simplex virus (HSV) [14,15] and SARS-CoV-2 [16,17]. It is also effective against the Enterovirus genus like enterovirus D68 (EV-D68) [18].

Among the Enterovirus genus, human enterovirus A71 (EV-A71) is notoriously known for causing epidemics of hand-foot-and-mouth disease (HMFD) among young children. Initially isolated in the United States in 1969 [19], EV-A71 later spread to Australia [20], Bulgaria [21], Japan [22] and Hungary [23]. By the 2000s, EV-A71 became widespread in the Asia-Pacific Region. Countries and regions such as Malaysia [24], Taiwan [25-28], Japan [29], Singapore [30,31] and China [32] had been experiencing recurring EV-A71 outbreaks throughout the years. China, within a short span of 7 years from 2008 to 2015, had tallied more than 13 million cases which includes 3,322 deaths [32].

Transmitted primarily by oral-fecal route [33], HFMD is a mild and self-limiting disease that affects young children. Clinical symptoms of HFMD include blisters appearing on the palms and soles, ulcerations in the mouth and on the tongue and fever [34]. HFMD can be caused by different members in the Enterovirus genus and while it typically resolves in a few days, cases caused by EV-A71 can result in more severe neurological and cardiopulmonary complications such as aseptic meningitis, brainstem encephalitis, pulmonary oedema and even death [34]. For example, a 1998 EV-A71 outbreak in Taiwan reported 129,106 HMFD or herpangina cases with 405 patients experiencing severe neurological and cardiopulmonary complications resulting in 78 deaths [25]. Recently, EV-A71 outbreaks involving severe complications had been observed in the United States [35] and European countries including Spain [36] and France [37], suggesting that the virus may be gradually spreading out of the Asia-Pacific region to other countries.

Unfortunately, there is no existing vaccine or antiviral treatment approved internationally for use against EV-A71. Current treatment mainly focuses on symptomatic relief. With rising cases of EV-A71 globally and the severe disease outcome associated with the infection, there is an urgent need to develop effective and potent antivirals against EVA71. As such, the ability of andrographolide to inhibit the Enterovirus genus piques our interest. We hypothesize that using andrographolide as a lead compound, we would be able to synthesize new derivatives that would be effective against EV-A71. Indeed, in China, an andrographolide sulfonate complex known as "Xiyanping" had already been adopted clinically to treat HFMD [38,39]. While the clinical efficacy of "Xiyanping" is mainly immunomodulatory [40], in this study we report novel andrographolide derivatives that have direct antiviral activity against EV-A71. Using andrographolide as a lead compound, we successfully synthesized 344 andrographolide derivatives and, upon an immunofluorescence-based high-throughput screen, we have identified 19 hits. Of these 19 compounds, ZAF-46 and ZAF-47 belonging to the same series exhibit potent anti-EVA71 activity and low cytotoxicity, following which, ZAF-47 was selected for downstream analyses to elucidate their possible antiviral mechanism of action.

\section{Results}

\subsection{High Throughput Screening of Compound Library Reveals Novel EV-A71 Inhibitors}

The screening assay was built using an immunofluorescence approach that was previously established and validated [41], with DAPI-stained nuclei accounting for total cell count and FITC-stained EV-A71 accounting for infected cell count upon EV-A71 infection and compound treatment. Both cell counts would then be used to calculate percentage infection and percentage inhibition to identify for hits. Before the screening platform can be employed to screen for potential antivirals, its robustness has to be appraised. In this study, Z-factor was calculated to assess the robustness of the screening platform. Firstly, seeded RD cells were either infected with EV-A71 (Multiplicity of Infection of 1) or mock-infected with media. The cells were then fixed, stained and imaged $12 \mathrm{~h}$ post-infection (hpi). The IFA 
images were analyzed with the Cell Profiler software to determine the infection rate of each well. Between the virus-infected and mock-infected wells, a clear distinction in infection rates could be observed (Figure $1 \mathrm{a}$ ). The closer $Z$-factor is to 1 , the greater the data quality and hence the robustness of the screening platform [42]. In this case, the Z-factor, measured at 0.818 , was indicative of a highly robust screening platform for high-throughput screening. The constructed screening platform was then employed to screen the compound library made up of 344 chemically synthesized novel compounds analogous to andrographolide. The compounds were screened at $10 \mu \mathrm{M}$ with IFA images taken and analyzed to identify for hits. Treatment with $0.1 \%$ DMSO was used as vehicle control. Hits were identified using two criteria: inhibition rate $>50 \%$ and nuclei count comparable to the $0.1 \%$ DMSO treated wells. From the EV-A71 screen, 36 compounds showed $>50 \%$ inhibition (Figure $1 \mathrm{~b}$ ) and 19 compounds were identified as hits (Table 1) and proceeded with validation studies.

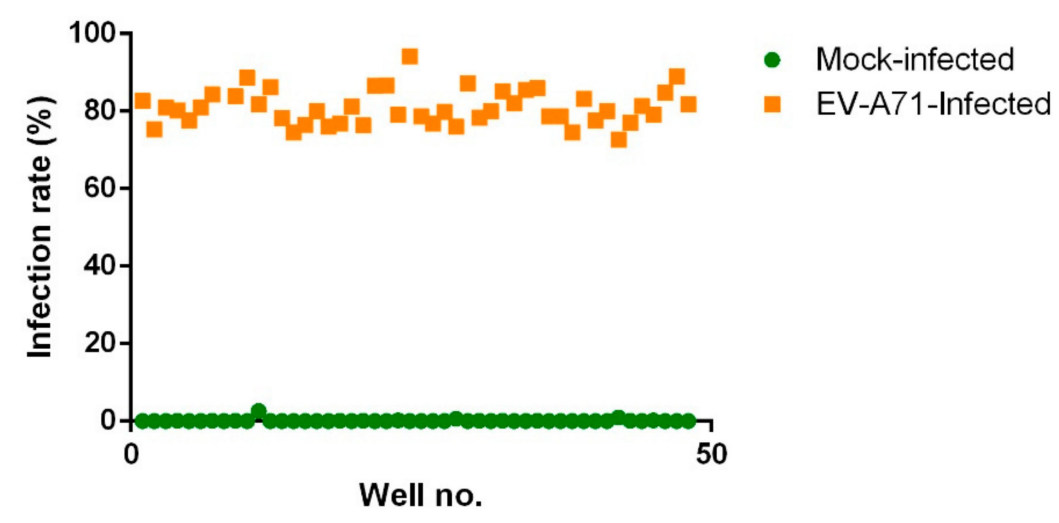

(a)

EV-A71-infected

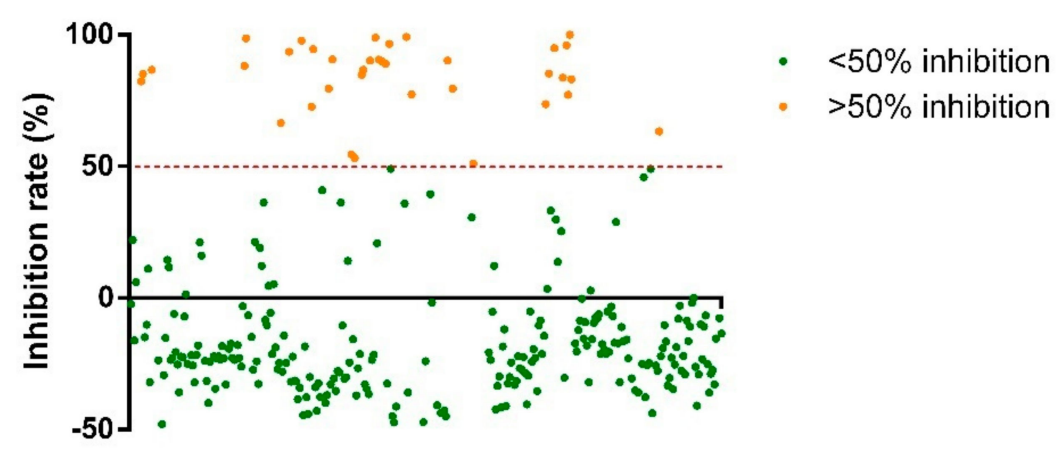

(b)

Figure 1. (a) The scatterplot represents the infection rates of individual wells, either EV-A71 infected or mock-infected. Z-factor, measured at 0.818 , was indicative of a highly robust screening platform for high-throughput screening. (b) The scatterplot represents the inhibition rates of all compounds screened on EV-A71-infected RD cells with 36 compounds found to have $>50 \%$ inhibition.

\subsection{Validation of $E V$-A71 Hits}

Firstly, we performed cell viability assay to evaluate the cytotoxicity profile of the 19 hits. Cells seeded overnight were treated with the hit compounds at $10 \mu \mathrm{M}$. Out of the 19 hits, 4 hits showed cell viability higher than 80\% (Figure 2a). Anti-EV-A71 activity of AGP-253 had been illustrated and discussed previously [43]. We were particularly interested in ZAF-46 and ZAF-47 as they belonged to the same series bearing novel 14-quinolinoxy and 17-hydro-8,9-olefin modifications (Figure 2b) that could potentially open up new targets for EV-A71 therapeutics. Additional cell viability assays were per- 
formed for ZAF-46 and ZAF-47 at different concentrations to identify the low cytotoxic concentrations for downstream post-treatment assays. For post-treatment assays, cells seeded overnight were infected with EV-A71 and subsequently treated with ZAF-46 and ZAF-47 at different concentrations. We found that treatment with either ZAF-46 or ZAF-47 led to a significant dose-dependent reduction in viral titres. Treatment with ZAF-46 led to $1.4 \log$ reduction at $10 \mu \mathrm{M}$ and $2.4 \log$ reduction at $20 \mu \mathrm{M}$ (Figure $2 \mathrm{c}$ ) while treatment with ZAF-47 led to $0.8 \mathrm{log}$ reduction at $5 \mu \mathrm{M}, 1.1 \mathrm{log}$ reduction at $10 \mu \mathrm{M}$ and $2.1 \log$ reduction at $20 \mu \mathrm{M}$ (Figure $2 \mathrm{~d}$ ). $\mathrm{CC}_{50}$ and $\mathrm{IC}_{50}$ for both compounds were determined and used to derive their SI (Table 2). ZAF-47 was selected for further downstream analysis due to its higher SI value which indicate higher pharmacological value for clinical use.

\subsection{Synthesis of ZAF-46 and ZAF-47}

As shown in Scheme 1, intermediate 2 was prepared according to the reported references $[44,45]$ by starting from andrographolide (1), and then the synthetic process from 2 to the 8,9-olifen 6 was adopted from our recently published method [46]. Briefly, acylation of 2 at 14-OH by $p$-nitrobenzoyl chloride provided compound 3, the olefin migration step of 8,17-olefin (3) to 8,9-olefin (4) was conducted by the treatment of $85 \% \mathrm{H}_{3} \mathrm{PO}_{4}$ followed by 3,19-protection of 4 by 2,2-dimethoxypropane and PPTS yielded 3,19-acetonylidene 5, de-acetylation at 14-position of 5 in methanol by Lithium carbonate afforded the key intermediate 6. After Mitsunobu reaction of 6 at 14-position was conducted to give 7, de-protection of 3,19-acetonylidene by $p$-TSA in methanol obtained diol 8, selectively acetylation by acetyl chloride of primary alcohol of 19-position afforded ZAF-46 and oxidation by DMP of 3-alcohol to 3-ketone produced ZAF-47.

Table 1. List of EV-A71 hits with nuclei count and inhibition rate tabulated.

\begin{tabular}{ccc}
\hline Compound & Nuclei Count & Inhibition Rate (\%) \\
\hline $0.1 \%$ DMSO & 998 & \\
AGF-57 & 845 & 85.02 \\
AGL-16 & 991 & 86.63 \\
AGP-8e & 1076 & 51.10 \\
ZAF-46 & 1037 & 96.04 \\
AGP-7 & 813 & 90.13 \\
AGP-72 & 914 & 79.59 \\
ZAF-47 & 955 & 77.14 \\
AGP-49 & 945 & 77.30 \\
AGP-254 & 873 & 90.52 \\
AGP-196 & 795 & 66.49 \\
AGP-261 & 999 & 88.91 \\
AGP-177 & 668 & 88.24 \\
AGP-253 [43] & 902 & 98.91 \\
AGP-263 & 1006 & 96.52 \\
AGP-240a & 780 & 84.83 \\
AGP-240b & 819 & 86.69 \\
AGP-218 & 816 & 94.62 \\
AGP-208 & 775 & 97.77 \\
AGP-236a & 885 & 53.13 \\
\hline
\end{tabular}

Table 2. $\mathrm{CC}_{50}, \mathrm{IC}_{50}$ and SI values of ZAF-46 and ZAF-47. SI $=\mathrm{CC}_{50} / \mathrm{IC}_{50}$. Both compounds exhibited antiviral activity against EV-A71. ZAF-47 was selected for mechanistic studies.

\begin{tabular}{ccc}
\hline Compound & ZAF-46 & ZAF-47 \\
\hline CC $_{\mathbf{5 0}}(\mu \mathrm{M})$ & 29.91 & 29.57 \\
IC $_{\mathbf{5 0}}(\boldsymbol{\mu M})$ & 4.44 & 2.06 \\
Selectivity Index (SI) & 6.73 & 14.35 \\
\hline
\end{tabular}




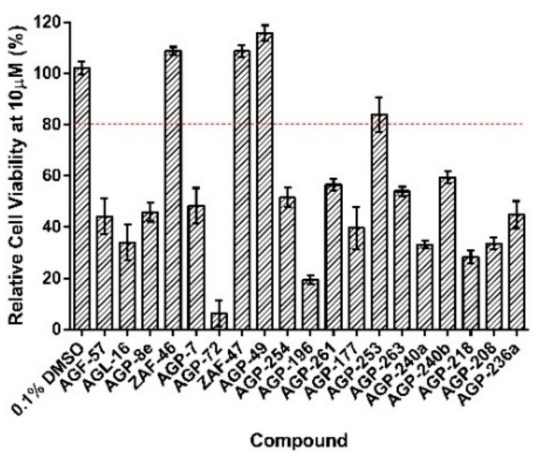

(a)

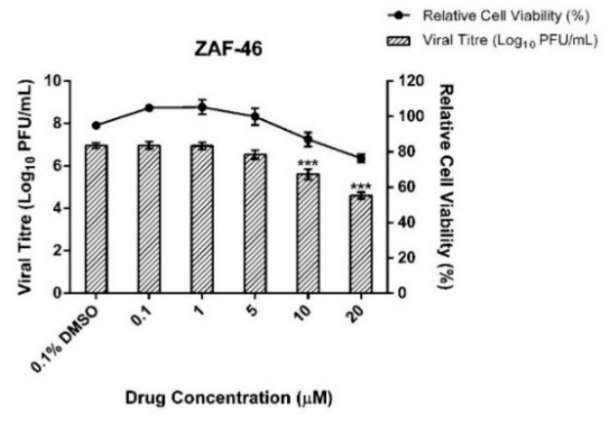

(c)

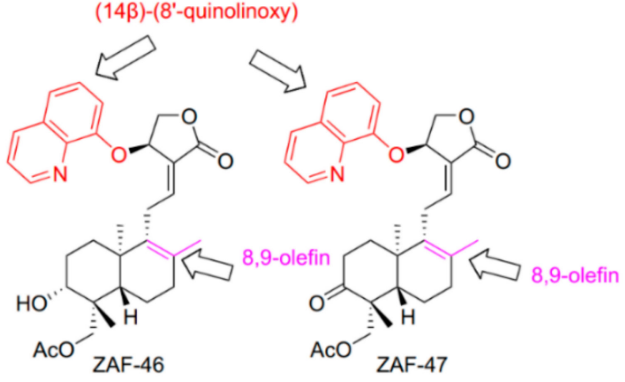

(b)

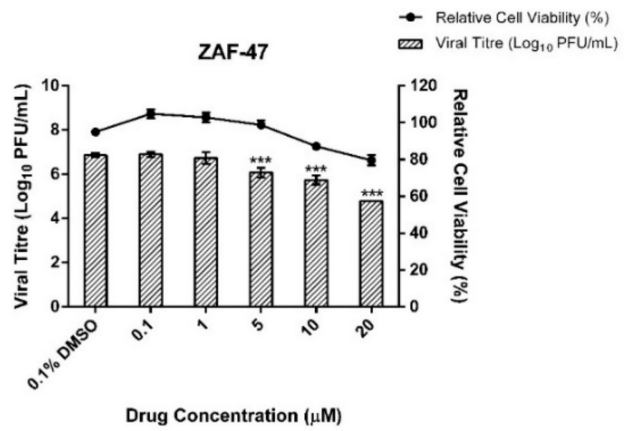

(d)

Figure 2. Validation of EV-A71 hits with cell viability and dose-dependent assays. (a) Treatment of RD cells with the 19 hits for 12 h showed that only 4 hits (ZAF-46, ZAF-47, AGP-49 and AGP-253 [43]) had low cytotoxicity at $10 \mu \mathrm{M}$. (b) ZAF-46 and ZAF-47 are novel derivatives of andrographolide with unique quinolinoxy and olefin modification. Treatment of EV-A71-infected RD cells with (c) ZAF-46 and (d) ZAF-47 at various concentrations. Both compounds inhibit EV-A71 in a dosedependent manner. Triplicates were performed with error bars plotted to show the mean and standard deviation. Data were evaluated with one-way ANOVA and Dunnett's test for statistical significance. *** signifies $p<0.001$.
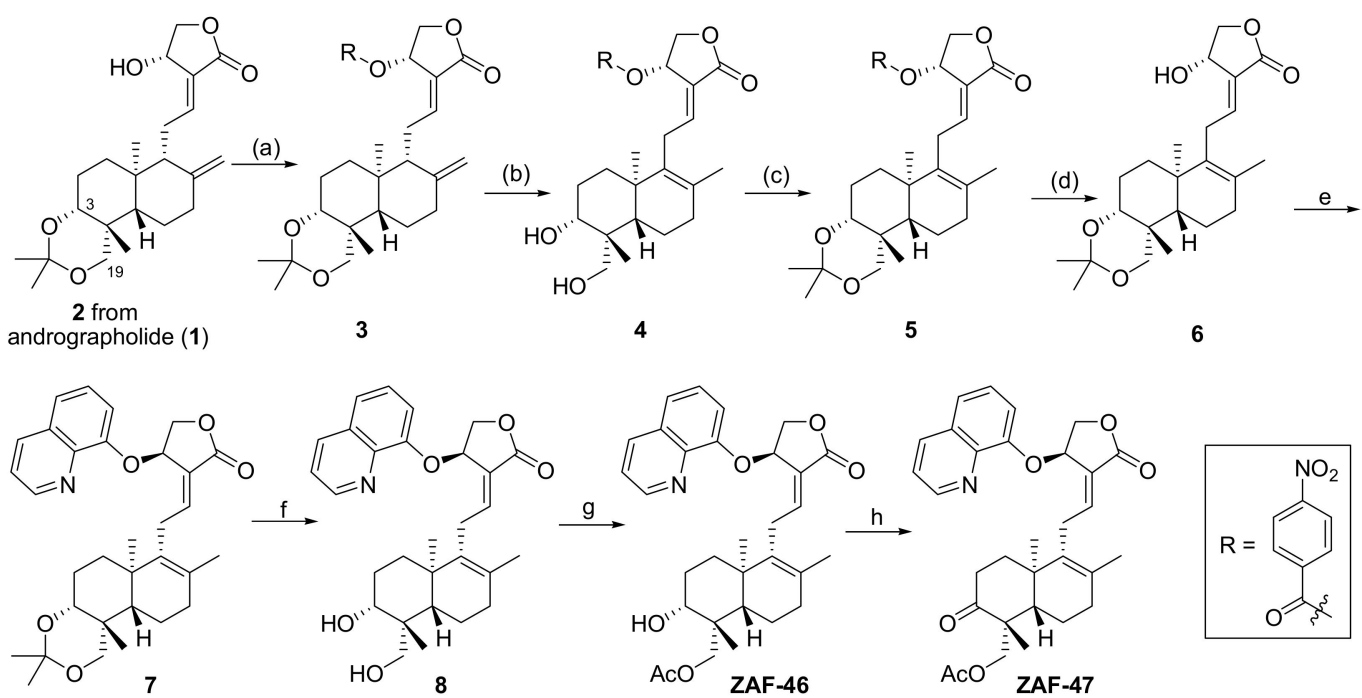

Scheme 1. Reagents and conditions: (a) 4-Nitrobenzoyl chloride, TEA, DCM, 91.1\%; (b) 85\% $\mathrm{H}_{3} \mathrm{PO}_{4}, 53.2 \%$; (c) 2,2-dimethoxypropane, PPTS, DCM, 81.5\%. (d) $\mathrm{Li}_{2} \mathrm{CO}_{3}, \mathrm{MeOH}, 69.9 \%$; (e) 8-Hydroxyquinoline, $\mathrm{PPh}_{3}$, DIAD, THF, 76.4\%; (f) $p$-TSA, $\mathrm{MeOH}, 63.8 \%$; (g) AcCl, TEA, DCM, $60.3 \%$; (h) DMP, $\mathrm{NaHCO}_{3}, \mathrm{DCM}, 75.8 \%$. 


\subsection{ZAF-47 Targets EV-A71 Post Entry Stages}

To determine the time window in the EV-A71 replication cycle in which the inhibitory activity of ZAF-47 remains active, we performed time-of-removal (TOR) and time-ofaddition (TOA) assays. ZAF-47 was either removed from or added on the infected cells at fixed time points and upon $12 \mathrm{hpi}$, all supernatants were collected to quantify the viral titres. TOR assay would enable us in pinpointing the time point whereby the removal of ZAF-47 would not remove any inhibitory effect and a plateauing of viral titre would be observed, whereas TOA assay would enable us in pinpointing the time point whereby the addition of ZAF-47 would no longer have any inhibitory effect and an increase in viral titre would be observed. Combining both assays, it was observed that plateauing of viral titre began after ZAF-47 was removed 4 hpi (Figure 3a) and only increased after ZAF-47 was added 6 hpi (Figure 3b). This suggests that the antiviral activity of ZAF-47 is likely to act between 4 and 6 hpi (Figure 3c) which according to EV-A71 growth kinetics [47], ZAF-47 possibly targets EV-A71 post-entry stages like RNA replication and protein translation.

To confirm this finding, assays to investigate the effect of ZAF-47 on EV-A71 entry into cells were performed. With pre-treatment assay, we first treated the cells with different concentrations of ZAF-47 before subjecting them to EV-A71 infection. The aim was to investigate if ZAF-47 was able to bind to host surface receptors which would prevent the virions from binding and thus blocking viral entry. Viral titre was quantified from the supernatant collected $12 \mathrm{hpi}$ and we found that, besides the highest concentration, treatment with ZAF-47 displayed similar viral titres to the DMSO control (Figure 3d). Even at the highest concentration, the reduction in viral titre $\left(0.8 \log _{10} \mathrm{PFU} / \mathrm{mL}\right.$ decrease $)$ was not as pronounced as post-treatment and could likely be due to drug toxicity. Thus, it is unlikely that ZAF-47 inhibits EV-A71 infection by binding with host receptors to block viral entry. With co-treatment assay, we first treated EV-A71 virions with ZAF-47 for $30 \mathrm{~min}$ before infecting the cells. The aim was to investigate if ZAF-47 was able to bind to viral surface proteins which would prevent the virions from binding to the host receptors and thus blocking viral entry. There was no significant difference between the viral titres of the supernatants collected from ZAF-47 treatment and DMSO treatment 12 hpi (Figure 3e). Thus, it is unlikely that ZAF-47 blocks EV-A71 entry into host cells by binding to viral surface proteins. Instead, using entry bypass assay, we were able to deduce that ZAF-47 most likely targets EV-A71 post-entry stages. With entry bypass assay, we transfected the cells with EV-A71 RNA instead, followed by treatment with different concentrations of ZAF-47. The aim was to simulate virus uncoating with transfection and investigate if ZAF-47 can inhibit EV-A71 post-entry stages after viral genome is released into the cytosol. Unsurprisingly, from the supernatant collected $12 \mathrm{hpi}$, we found that treatment with ZAF47 resulted in significant viral reductions of $0.9 \log$ at $10 \mu \mathrm{M}$ and $2.6 \log$ at $20 \mu \mathrm{M}$ (Figure 3f). This finding aligned with previous results and suggests that ZAF-47 inhibits EV-A71 post entry stages.

\subsection{ZAF-47 Reduces Expression of EV-A71 Viral Proteins by Specifically Targeting EV-A71 RNA Replication}

Since ZAF-47 possibly targets EV-A71 post-entry stages, we were interested in looking at the effect of ZAF-47 on EV-A71 protein expression. To do so, we first infected RD cells with EV-A71. We then treated the infected cells with different concentration of ZAF-47 for $6 \mathrm{~h}$ and collected the cell lysates for SDE-PAGE and Western blot. Analysed with the vehicle control, we found that treatment with ZAF-47 resulted in significant drop in band intensities of EV-A71 proteins, VP2 $(28 \mathrm{kDa})$ and VP0 $(36 \mathrm{kDa})$. VP2 band could been seen with the vehicle control but not with any ZAF-47 treatment while VP0 band could be seen with ZAF-47 treatment at $5 \mu \mathrm{M}$ but the intensity was reduced by 35 -fold in comparison to the control (Figure $4 a, b$ ) after normalization with the detected loading control, $\beta$-actin. These observations showed that treatment with ZAF-47 can reduce EV-A71 protein expression in host cells. Since ZAF- 47 acts on the post-entry stages and reduces 
EV-A71 protein expression, we hypothesized that ZAF-47 could be inhibiting RNA replication or protein translation, or possibly both, resulting in reduced viral protein expression.

Time-of-Removal: ZAF-47

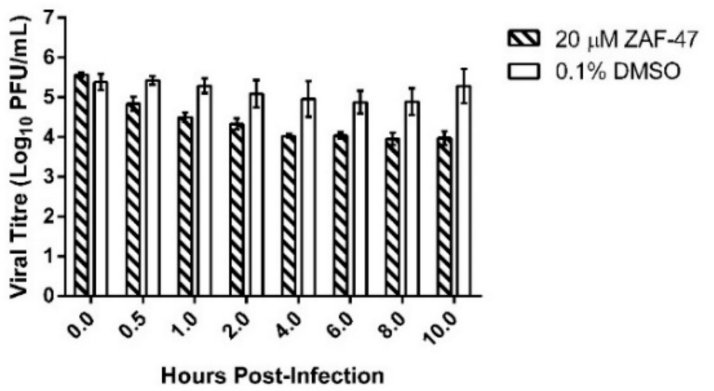

(a)

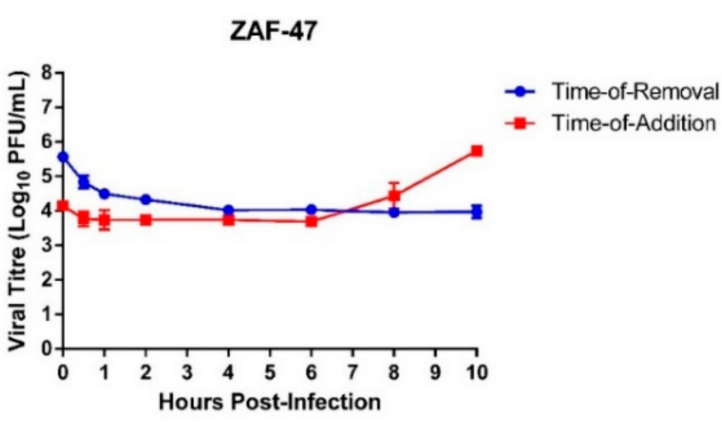

(c)

Co-treatment: ZAF-47

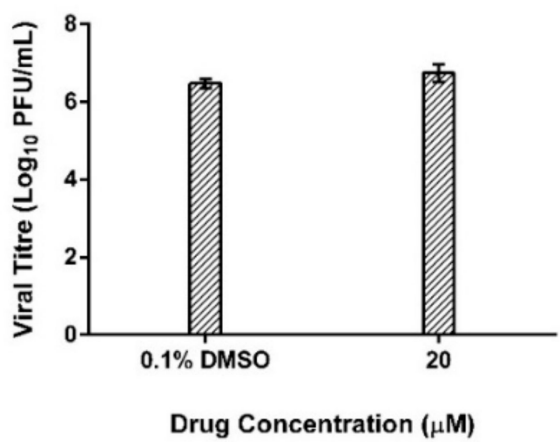

(e)
Time-of-Addition: ZAF-47

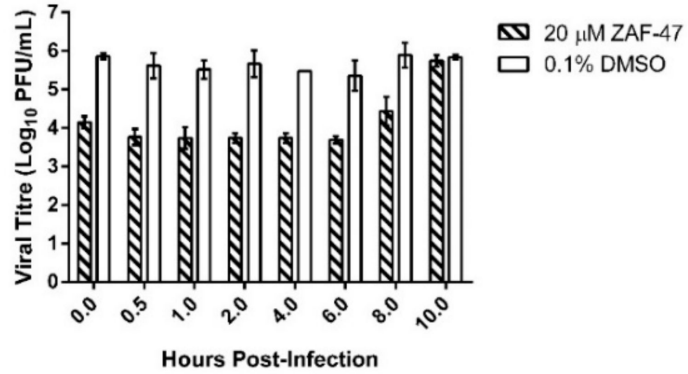

(b)

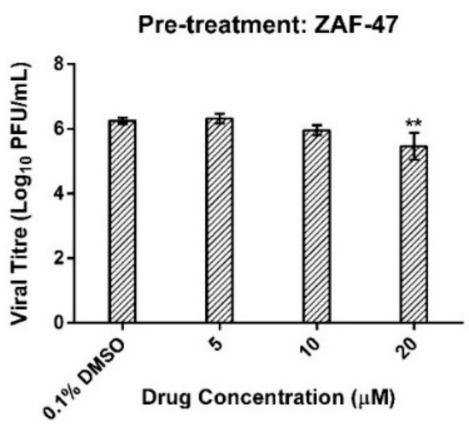

(d)

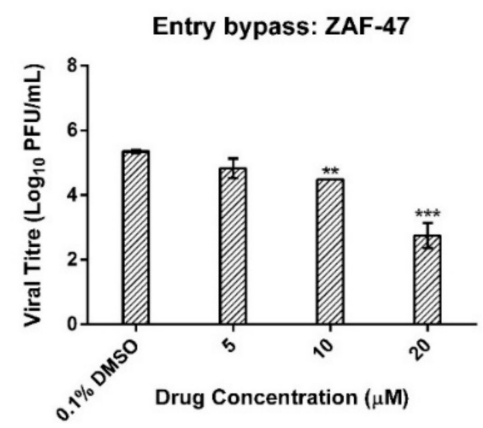

(f)

Figure 3. ZAF-47 acts EV-A71 post-entry stages. (a) TOA and (b) TOR assays were performed with either $20 \mu \mathrm{M}$ ZAF-47 or $0.1 \%$ DMSO at pre-determined timepoints. (c) Combined graphs from both assays suggest that ZAF-47 acts between 4 and 6 hpi. (d) Pre-treatment assay showed only significant difference in viral titre with the control at the highest concentration used suggests that ZAF-47 is unlikely to inhibit viral entry by binding to host receptors. (e) Co-treatment assay displayed no significant difference between control and ZAF-47-treated suggests that ZAF-47 is unlikely to inhibit viral entry by binding to viral surface proteins. (f) Entry bypass assay displayed significant dose-dependent viral titre reduction suggests that ZAF-47 possibly targets EV-A71 post-entry stages. Triplicates were performed with error bars plotted to show the mean and standard deviation. Data were evaluated with one-way ANOVA and Dunnett's test for statistical significance. ${ }^{* *}$ signifies $p<0.01$ and ${ }^{* * *}$ signifies $p<0.001$. 


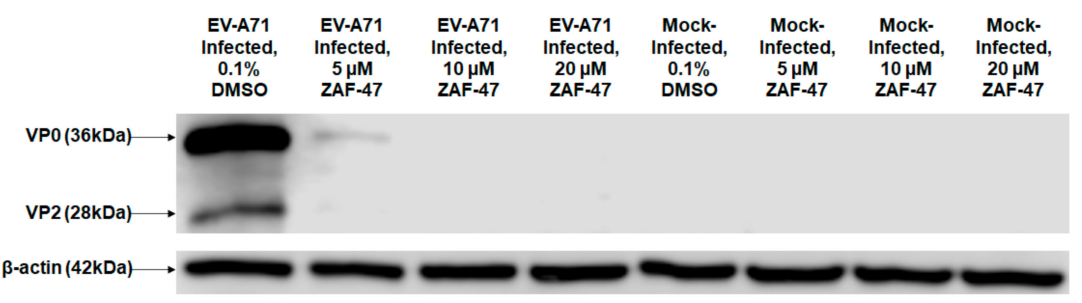

(a)

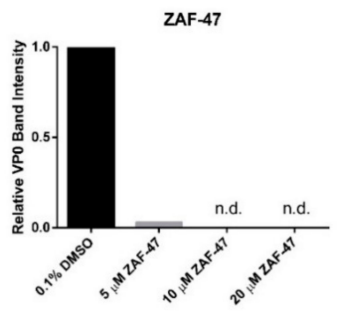

(b)

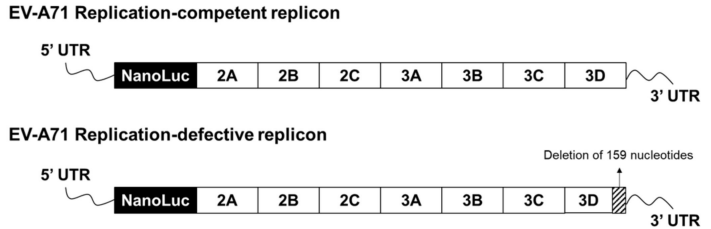

(c)

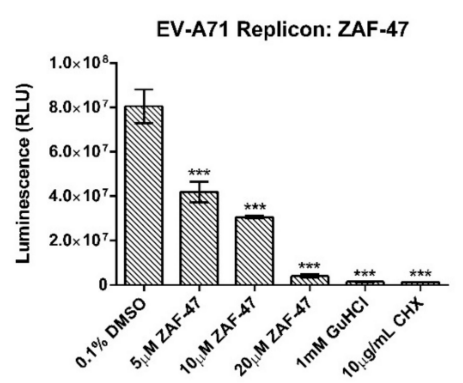

(d)

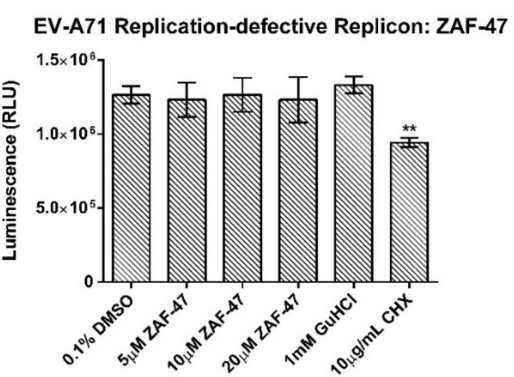

(e)

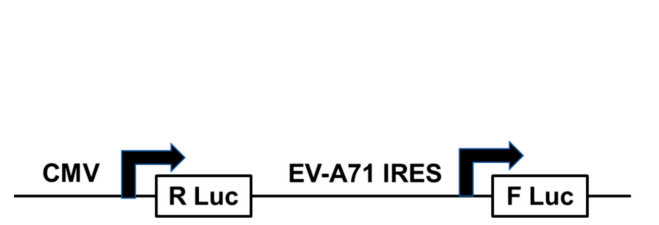

(f)

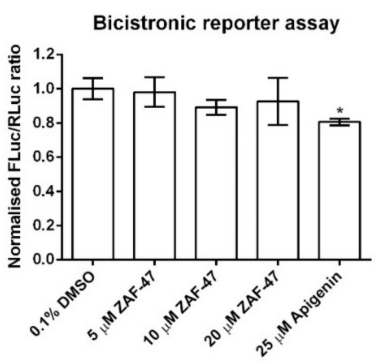

(g)

Figure 4. ZAF-47 reduces expression of EV-A71 viral proteins by specifically targeting EV-A71 RNA replication. (a) Western blot displayed reduced band intensities at 6 hpi for VP0 and VP2 after ZAF-47 treatment showed that ZAF-47 inhibits EV-A71 protein expression in infected cells. (b) Relative VP0 band intensity from ZAF-47-treated samples were compared with DMSO control. (c) EV-A71 RNA replicons (replication-competent and replication-defective) utilized for nano-luciferase reporter assay. (d) Luminescence readings of cells transfected with replication-competent replicon. Treatment with ZAF-47 reduces luminescence in a dose-dependent manner. (e) Luminescence readings of cells transfected with replication-defective replicon. ZAF-46 treatment did not reduce any luminescence. (f) Bicistronic reporter construct utilized for bicistronic luciferase reporter assay. (g) FLuc/RLuc ratios from cells transfected with bicistronic luciferase construct. FLuc/RLuc ratio is reflective of IRES activity. Treatment with ZAF-47 led to no significant reduction in IRES activity. Thus, antiviral activity of ZAF-47 is only specific to EV-A71 RNA replication. Triplicates were performed with error bars plotted to show the mean and standard deviation. Data were evaluated with one-way ANOVA and Dunnett's test for statistical significance. ${ }^{*}$ signifies $p<0.05,{ }^{* *}$ signifies $p<0.01$ and *** signifies $p<0.001$. 
To identify specifically which of these two intrinsically linked processes that ZAF-47 inhibits, we transfected RD cells with EV-A71 RNA replicons that were either replicationcompetent or replication-defective and subsequently treated them with different concentrations of ZAF-47 for $12 \mathrm{~h}$ before detecting for luminescence. Both forms of replicons were previously established and validated [48]. The replication-competent replicon is capable of self-replicating as it contains an intact 3D region that encodes for 3D polymerase $\left(3 \mathrm{D}^{\mathrm{pol}}\right)$ responsible for RNA replication [49] (Figure 4c). Hence, cells containing the replication-competent replicon express luciferase upon IRES translation of the original replicons as well as the replicated copies. In contrast, the replication-defective replicon contains a 3D region with 159 nucleotide deletion which would produce a non-functional 3D protein and impair RNA replication (Figure 4c). As such, cells containing the replicationdefective replicon express luciferase upon IRES translation of the original replicons only. The transfected cells were also treated with negative control, DMSO and positive controls, guanidine hydrochloride $(\mathrm{GuHCl})$ and cycloheximide $(\mathrm{CHX})$, a RNA replication-specific inhibitor [50] and a general translation inhibitor [51] respectively. It was observed that ZAF-47 treatment resulted in significant decrease in luminescence in a dose-dependent manner in cells containing the replication-competent replicon and not in cells containing the replication-defective replicon, similar to $\mathrm{GuHCl}$ (Figure $4 \mathrm{~d}, \mathrm{e}$ ). This shows that ZAF-47 is capable in inhibiting viral RNA replication and not IRES translation, indicating that the antiviral activity of ZAF-47 is specific to EV-A71 RNA replication.

To validate this finding, we also transfected RD cells with a bicistronic reporter construct which had been established and validated previously [52]. Similarly, the transfected cells were treated with ZAF-47 at various concentrations and then incubated for $12 \mathrm{~h}$ before luminescence detection. The construct comprises a human cytomegalovirus (CMV) promoter with a downstream Renilla luciferase (R Luc) gene and an EV-A71 strain 41 IRES with a downstream firefly luciferase (F Luc) gene (Figure 4f). This means that R Luc can be expressed by the CMV promoter via cap-dependent translation while F Luc can be expressed by the EV-A71 IRES via cap-independent translation. An accurate determination of IRES activity would be to use the ratio of $F$ Luc luminescence reading to $\mathrm{R}$ Luc luminescence reading (F Luc/R Luc). The transfected cells were also treated with negative control, DMSO and positive control, apigenin, an EV-A71 IRES inhibitor [53]. It was observed that ZAF-47 treatment did not reduce IRES activity in any of the concentration used (Figure $4 \mathrm{~g}$ ). This suggests that ZAF-47 indeed does not inhibit EV-A71 IRES translation.

\subsection{ZAF-47 Possibly Targets Host Factor/s Associated with EV-A71 RNA Replication}

EV-A71 was repeatedly passaged in RD cells together with a low initial ZAF-47 concentration that was gradually increased overtime, to select for resistant mutants that would give us better insight in identifying the possible targets of ZAF-47 in EV-A71 RNA replication. Unfortunately, we were unable to obtain any resistant mutants as the viral titre for ZAF-47-treated remained lower than that of the controls at Passage 21. By infecting RD cells with the supernatant collected from Passage 21 at MOI = 1 and subsequently treating them with ZAF-47, we found that ZAF-47 is still capable of inhibiting the passaged virus dose-dependently (Figure 5). As a result, we hypothesize that ZAF-47 possibly targets host factor/s associated with EV-A71 RNA replication which makes it harder to generate resistant mutants. 


\section{Passage 21}

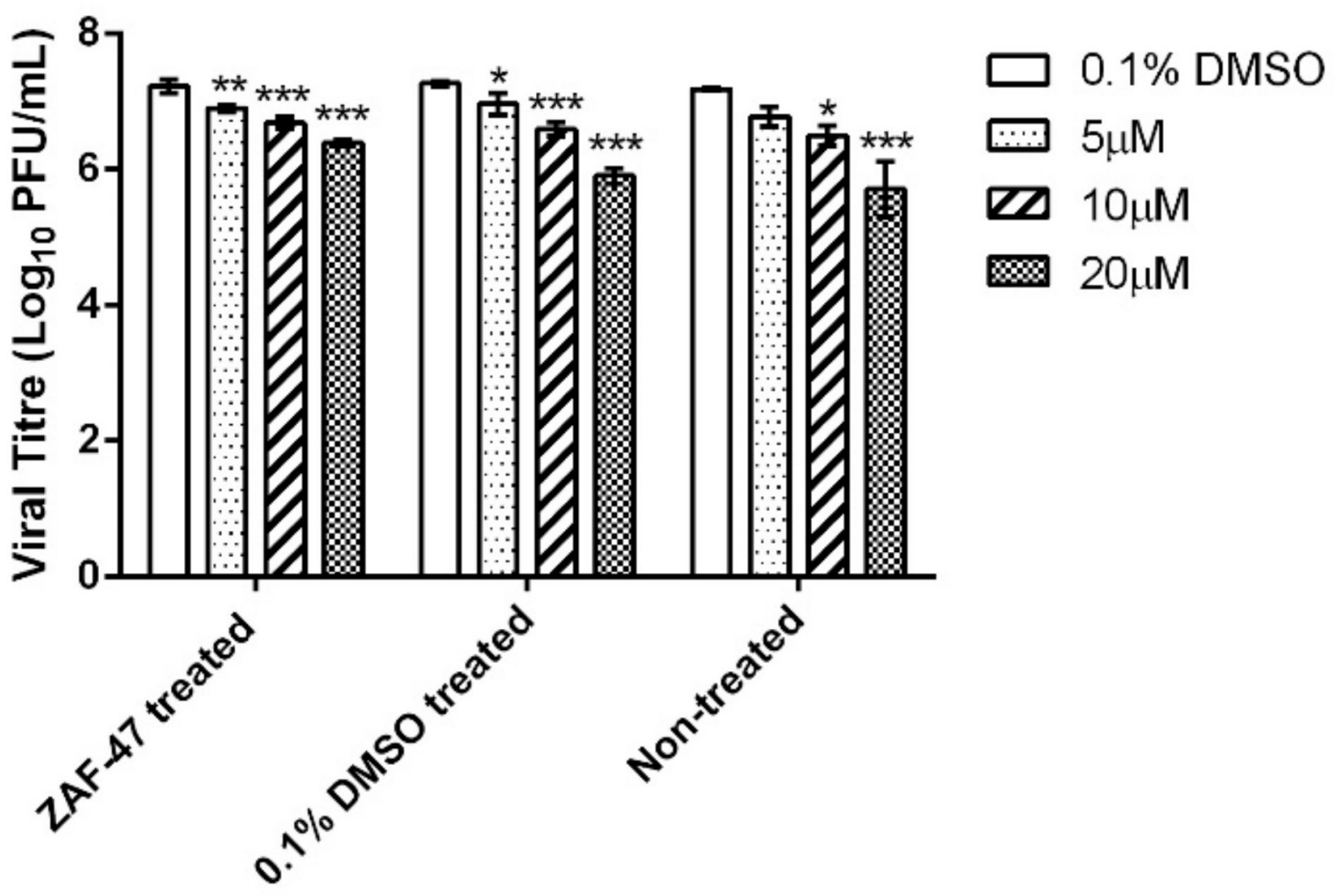

Figure 5. Post-treatment assay using EV-A71 passaged 21 times in RD cells in the presence of ZAF-47. Treatment with ZAF-47 led to significant viral titre reductions. This suggests that the passaged virus has not develop any resistance. Triplicates were performed with error bars plotted to show the mean and standard deviation. Data were evaluated with one-way ANOVA and Dunnett's test for statistical significance. ${ }^{*}$ signifies $p<0.05,{ }^{* *}$ signifies $p<0.01$ and ${ }^{* * *}$ signifies $p<0.001$.

\subsection{Broad-Spectrum Anti-enterovirus Activity of ZAF-47}

We were also interested in the antiviral potential of ZAF-47 against other Enteroviruses. As such, we performed post-treatment assay on RD cells infected with other Enteroviruses such as CV-A16, CV-A6, Echo7, CV-B5, CV-A24 and EV-D68. ZAF-47, at $10 \mu \mathrm{M}$, was capable in reducing the viral titres of the above-listed enteroviruses significantly (Figure 6a-f). The respective $\mathrm{IC}_{50}$ values upon $\mathrm{ZAF}-47$ treatment for the different enteroviruses were tabulated in Table 3. The effectiveness of ZAF-47 against at least four different species of Enterovirus suggests that it can function as a broad-spectrum anti-enterovirus agent which is highly useful against HFMD, a common disease caused by different enteroviruses.

Table 3. $\mathrm{IC}_{50}$ values of ZAF-47 treated on other Enteroviruses.

\begin{tabular}{cccc}
\hline Enterovirus & Species & $\begin{array}{c}\text { Drug Treatment } \\
\text { Duration }(\mathbf{h})\end{array}$ & IC $_{\mathbf{5 0}}(\boldsymbol{\mu M})$ \\
\hline CV-A6 & Enterovirus A & 96 & 3.16 \\
CV-A16 & Enterovirus A & 16 & 1.38 \\
Echo7 & Enterovirus B & 12 & 6.70 \\
CV-B5 & Enterovirus B & 12 & 2.46 \\
CV-A24 & Enterovirus C & 12 & 1.09 \\
EV-D68 & Enterovirus D & 12 & 5.10 \\
\hline
\end{tabular}


CV-A6

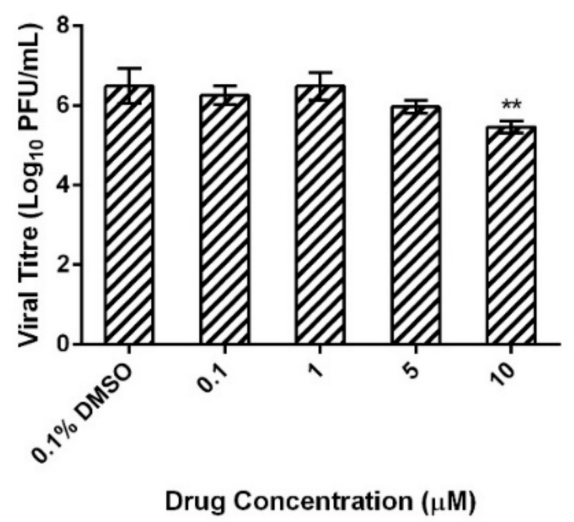

(a)

Echo7

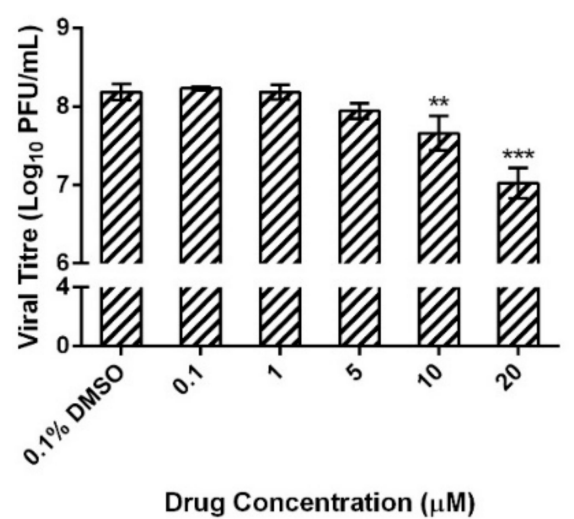

(c)

CV-A24

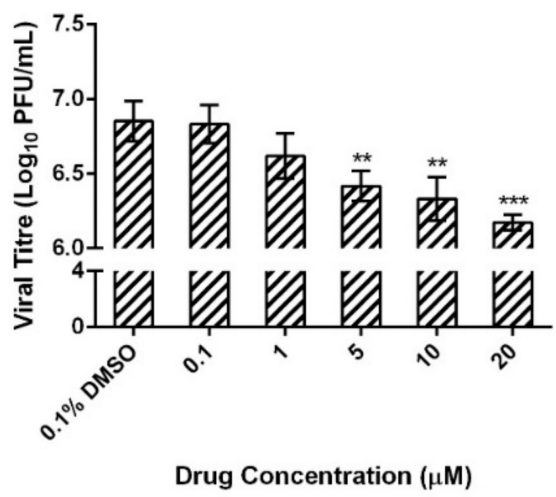

(e)
CV-A16

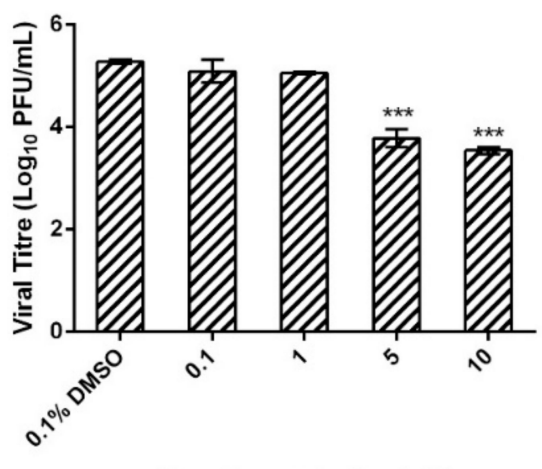

Drug Concentration $(\mu \mathrm{M})$

(b)

CV-B5

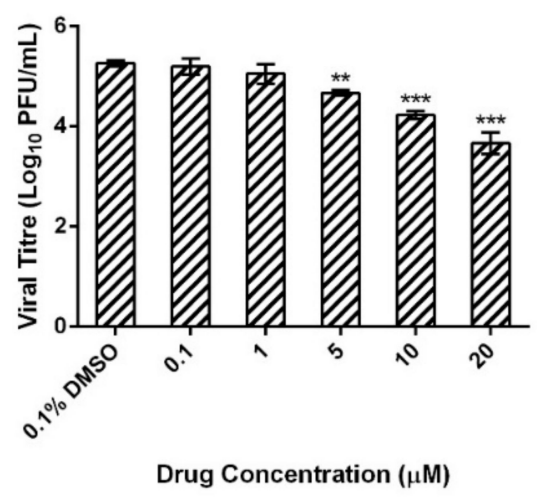

(d)

EV-D68

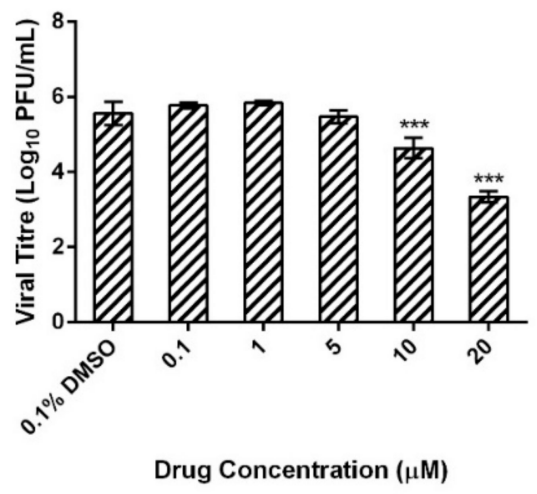

(f)

Figure 6. (a) CV-A6, (b) CV-A16, (c) Echo7, (d) CV-B5, (e) CV-A24 and (f) EV-D68 -infected cells were treated with ZAF-47 at different concentrations. Quantified viral titres from the supernatant using viral plaque assay showed that ZAF-47 can inhibit the different enteroviruses tested which suggests a broad-spectrum anti-enterovirus potential that is highly useful against HFMD. Triplicates were performed with error bars plotted to show the mean and standard deviation. Data were evaluated with one-way ANOVA and Dunnett's test for statistical significance. ${ }^{* *}$ signifies $p<0.01$ and *** signifies $p<0.001$. 


\section{Discussion}

In the last two decades, EV-A71 had become endemic across the Asia-Pacific region, causing major outbreaks every few years and resulting in many fatalities and severe neurological complications [33]. Recently, however, it has started to spread out of the region to countries such as the United States [35], Spain [36] and France [37]. With the lack of an internationally approved vaccine or antiviral against these infections and the rapid spread of virus to other parts of the world, there is a crucial need for the development of safe and potent antivirals to combat this persistent global public health problem.

Historically, phenotypic screening has been used for discovery of new drugs. While there has been a paradigm shift to a target-based approach in recent years, many first-inclass drugs with novel modes of action still derived from phenotypic screening [54]. This was shown in our study that by using an immunofluorescence-based phenotypic screen, we were able to identify novel andrographolide derivatives that inhibit EV-A71 infection. Andrographolide is a major constituent of the medicinal plant Andrographis paniculate which has an extensive range of therapeutic capabilities including antiviral properties [4]. In China, the sulfonate derivative known as "Xiyanping" is used to treat HFMD with good clinical efficacy $[38,39]$. Yet, despite its notable pharmacological activities, andrographolide has low water solubility and poor bioavailability [55]; thus, we sought to improve its pharmacology with novel chemical modifications. We successfully synthesized 344 novel andrographolide derivatives and, with the use of a phenotypic screen, we were able to identify 19 anti-EV-A71 hits.

Among the hits, we had previously reported on the anti-EV-A71 activity of AGP253 [43]; however, we were more interested in ZAF-46 and ZAF-47 due to the 8,9-olefin and 14-quinolinoxy modifications they contain which were structurally distinct from AGP-253. From the literature, some 9-dehydro-17-hydro analogues increase neuroprotective properties [56] and are more efficient against angiogenesis $[57,58]$ than their 8,17olefinic counterpart. These results envision that olefinic transformation from 8,17-olefin to 8,9-olefin is valuable modification direction to discover more potent antivirals based on andrographolide's antiviral scaffold [38,40,44,59]. In addition, chloroquinoline and hydroxychloroquinoline were reported to be antiviral agents including as ZIKV [60,61] and SARS-CoV-2 [62] inhibitors, and quinoline moiety was broadly used as building blocks in many anti-infectious drug discoveries [63-66]. From subsequent post-treatment assays, we found that ZAF-46 was capable of reducing EV-A71 viral titre at $10 \mu \mathrm{M}$ and $20 \mu \mathrm{M}$ with a $\mathrm{CC}_{50}$ of $29.91 \mu \mathrm{M}$ and $\mathrm{IC}_{50}$ of $4.44 \mu \mathrm{M}$ while ZAF-47 was capable of reducing EV-A71 viral titre at $5 \mu \mathrm{M}, 10 \mu \mathrm{M}$ and $20 \mu \mathrm{M}$ with a $\mathrm{CC}_{50}$ of $29.57 \mu \mathrm{M}$ and IC $_{50}$ of $2.06 \mu \mathrm{M}$. We were intrigued by how the modified derivatives were able to inhibit EV-A71 infection, so we performed mechanistic studies on ZAF-47, the more potent of the two compounds (it has a better selectivity index of 14.35).

From the TOA and TOR assays, we found that the antiviral activity of ZAF-47 acts between 4 hpi to 6 hpi and according to the previous work on EV-A71 viral kinetics [47], this time window seems to correspond to the viral RNA replication and protein translation stages. Nevertheless, we also performed experiments that investigate the effect of ZAF-47 on the viral entry stages and we found that ZAF-47 reduces EV-A71 titres in entry bypass assay but not pre-treatment and co-treatment assays which suggests that, indeed, ZAF-47 acts on EV-A71 post-entry stages. Through the use of Western blot and luciferase assays, we narrowed down the antiviral activity of ZAF-47 to targeting EV-A71 RNA replication specifically. Besides EV-A71, ZAF-47 was also able to inhibit other enteroviruses which suggests that it is either acting on a common host factor, since the RD cells were used in all infections, or acting on a viral factor found universally in Enteroviruses. The former is likely to be the case as we were unable to generate resistant mutants despite repeatedly passaging EV-A71 with ZAF-47. To summarize, we were able to identify novel andrographolide derivatives as EV-A71 inhibitors using an immunofluorescence-based screening approach. ZAF-47, a quinolinoxy-andrographolide derivative, was discovered to inhibit EV-A71 RNA replication specifically. 
Andrographolide has a multi-targeting nature [67]. One of the targets that it inhibits is the NF-kB signaling pathway shown to be essential for EV-A71 replication and EV-A71-induced inflammatory responses [68,69]. However, it was reported that the increased survival of EV-A71-infected mice using andrographolide sulfonate is due to its immunomodulating effect rather than its antiviral effect [40]. In contrast, andrographolide was able to suppress viral replication of the related EV-D68 by preventing acidification of virus-containing endosomes [18] and our previous work on an epoxy andrographolide derivative was shown to inhibit EV-A71 RNA replication [43]. As such, we believe andrographolide and its derivatives such as ZAF-47 can have multiple targets in inhibiting EV-A71 infection. Thus, while we hypothesize that ZAF-47 plausibly targets a host factor responsible for EV-A71 RNA replication, we also do not rule out the possibility of it being a viral factor, especially since andrographolide was reported to have high affinity to SARS-CoV-2 RNA-dependent RNA polymerase (NSP12) [70]. In addition, the quinolinoxy modification in ZAF-47 could have enhanced its antiviral capability by having a direct or indirect effect on the inhibition of EV-A71 RNA replication. It was reported that some quinolone-based drugs were able to inhibit HIV-1 replication by binding to RNA and interfering with Tat-TAR interaction [64]. By binding to RNA, the quinolinoxy group may have direct inhibition on EV-A71 RNA replication or indirectly by bringing andrographolide close to the site of replication where andrographolide can bind to its target to inhibit EV-A71 RNA replication. Further work needs to be done to identify the specific target(s) of ZAF-47 in EV-A71 RNA replication.

\section{Materials and Methods}

\subsection{Synthesis of ZAF-46 and ZAF-47}

4.1.1. (14ß)-(8'-Quinolinoxy)-9-dehydro-17-hydro-3,19-isopropyleneoxyandrographolide (7)

Under an inert atmosphere, the solution of compound 6 [46] (1 g, $2.56 \mathrm{mmol})$, triphenylphosphine $\left(\mathrm{PPh}_{3}\right)(1.01 \mathrm{~g}, 3.84 \mathrm{mmol})$ and 8-hydroxyquinoline $(0.56 \mathrm{~g}, 3.84 \mathrm{mmol})$ in anhydrous tetrahydrofuran $(10 \mathrm{~mL})$ was cooled by iced water and then added dropwise diisopropyl azodicarboxylate $(0.75 \mathrm{~mL}, 3.84 \mathrm{mmol})$. The reaction was monitored by TLC to indicate the reaction was complete in $3 \mathrm{~h}$. The reaction solvent was evaporated, the residue was dissolved and extracted with ethyl acetate, washed twice with saturated aqueous sodium chloride solution, and the organic phase was dried over anhydrous $\mathrm{Na}_{2} \mathrm{SO}_{4}$. The organic phase was evaporated to dryness, and column chromatography was performed to obtain compound 7: 76.4\% yield; white solid; m.p. $72.5-74.3{ }^{\circ} \mathrm{C}$; ${ }^{1} \mathrm{H} \mathrm{NMR}(400 \mathrm{MHz}$, DMSO- $\left.d_{6}\right) \delta 8.89(\mathrm{dd}, J=4.2,1.8 \mathrm{~Hz}, 1 \mathrm{H}), 8.39(\mathrm{dd}, J=8.4,1.7 \mathrm{~Hz}, 1 \mathrm{H}), 7.69(\mathrm{dd}, J=8.4$, $1.2 \mathrm{~Hz}, 1 \mathrm{H}), 7.62-7.53(\mathrm{~m}, 2 \mathrm{H}), 7.33(\mathrm{dd}, J=7.7,1.3 \mathrm{~Hz}, 1 \mathrm{H}), 6.73(\mathrm{t}, J=6.5 \mathrm{~Hz}, 1 \mathrm{H}), 6.14$ $(\mathrm{d}, J=5.4 \mathrm{~Hz}, 1 \mathrm{H}), 4.75(\mathrm{dd}, J=10.8,5.5 \mathrm{~Hz}, 1 \mathrm{H}), 4.57-4.48(\mathrm{~m}, 1 \mathrm{H}), 3.85(\mathrm{~d}, J=11.6 \mathrm{~Hz}$, $1 \mathrm{H}), 3.11(\mathrm{~d}, J=11.6 \mathrm{~Hz}, 1 \mathrm{H}), 2.86(\mathrm{qd}, J=17.8,6.7 \mathrm{~Hz}, 2 \mathrm{H}), 1.94(\mathrm{~s}, 2 \mathrm{H}), 1.83(\mathrm{~s}, 1 \mathrm{H}), 1.67$ $(\mathrm{s}, 2 \mathrm{H}), 1.56(\mathrm{~s}, 1 \mathrm{H}), 1.45(\mathrm{~s}, 3 \mathrm{H}), 1.31(\mathrm{~s}, 3 \mathrm{H}), 1.26(\mathrm{~s}, 3 \mathrm{H}), 1.21-1.14(\mathrm{~m}, 2 \mathrm{H}), 1.10(\mathrm{~s}, 3 \mathrm{H})$, 0.95 (s, 3H), 0.89-0.82 (m, 2H); ${ }^{13} \mathrm{C}$ NMR (101 MHz, Chloroform- $\left.d\right) \delta 169.9,152.5,151.3$, $149.5,141.5,136.6,136.2,129.9,128.8,126.6,124.4,122.9,121.8,116.2,99.1,76.1,74.2,71.5$, $63.9,48.6,37.7,37.7,33.6,32.3,28.9,26.8,25.9,25.5,24.9,22.0,19.5,18.3$. HRMS (ESI) $\mathrm{m} / z$ $518.2904[\mathrm{M}+\mathrm{H}]^{+}$, calculated for $\mathrm{C}_{32} \mathrm{H}_{40} \mathrm{NO}_{5}, 518.2904$.

\subsection{2. (14ß)-(8'-Quinolinoxy)-9-dehydro-17-hydro-andrographolide (8)}

Compound 7 (0.95 g, $1.84 \mathrm{mmol})$ was dissolved in $10 \mathrm{~mL}$ methanol, and then treated with $p$-toluenesulfonic acid ( $p$-TSA) $(0.035 \mathrm{~g}, 0.184 \mathrm{mmol})$ at room temperature for $1 \mathrm{~h}$. TLC detected reaction progress. After compound 7 consumed completely, the reaction solvent was evaporated and the residue was dissolved and extracted with ethyl acetate, washed twice with saturated aqueous sodium chloride solution, and the organic phase was dried over anhydrous $\mathrm{Na}_{2} \mathrm{SO}_{4}$. The organic phase was filtered, evaporated to dryness, and purified by silica gel column chromatography to afford 8: $63.8 \%$ yield; white solid; m.p. $157.5-159.2{ }^{\circ} \mathrm{C} ;{ }^{1} \mathrm{H}$ NMR $\left(400 \mathrm{MHz}, \mathrm{DMSO}-d_{6}\right) \delta 8.89(\mathrm{dd}, J=4.2,1.8 \mathrm{~Hz}, 1 \mathrm{H}), 8.39$ 
$(\mathrm{dd}, J=8.4,1.7 \mathrm{~Hz}, 1 \mathrm{H}), 7.69(\mathrm{dd}, J=8.4,1.2 \mathrm{~Hz}, 1 \mathrm{H}), 7.62-7.53(\mathrm{~m}, 2 \mathrm{H}), 7.33(\mathrm{dd}, J=7.7$, $1.3 \mathrm{~Hz}, 1 \mathrm{H}), 6.73(\mathrm{t}, J=6.5 \mathrm{~Hz}, 1 \mathrm{H}), 6.14(\mathrm{~d}, J=5.4 \mathrm{~Hz}, 1 \mathrm{H}), 4.75(\mathrm{dd}, J=10.8,5.5 \mathrm{~Hz}, 1 \mathrm{H})$, $4.57-4.48(\mathrm{~m}, 1 \mathrm{H}), 3.85(\mathrm{~d}, J=11.6 \mathrm{~Hz}, 1 \mathrm{H}), 3.11(\mathrm{~d}, J=11.6 \mathrm{~Hz}, 1 \mathrm{H}), 2.86(\mathrm{qd}, J=17.8,6.7$ $\mathrm{Hz}, 2 \mathrm{H}), 1.94(\mathrm{~s}, 2 \mathrm{H}), 1.83(\mathrm{~s}, 1 \mathrm{H}), 1.67(\mathrm{~s}, 2 \mathrm{H}), 1.56(\mathrm{~s}, 1 \mathrm{H}), 1.45(\mathrm{~s}, 3 \mathrm{H}), 1.31(\mathrm{~s}, 3 \mathrm{H}), 1.26$ (s, 3H), 1.21-1.14 (m, 2H), $1.10(\mathrm{~s}, 3 \mathrm{H}), 0.95$ (s, 3H), 0.8-0.82 (m, 2H); ${ }^{13} \mathrm{C}$ NMR $(101 \mathrm{MHz}$, Chloroform-d) $\delta 169.9,152.4,151.1,149.5,141.3,136.3,136.1,129.9,129.5,126.6,124.5,122.8$, $121.9,115.6,80.4,74.0,71.8,64.1,51.7,42.7,38.4,34.8,34.2,28.5,28.0,22.5,20.4,19.4,18.7$; HRMS (ESI) $m / z 478.2591[\mathrm{M}+\mathrm{H}]^{+}$, calculated for $\mathrm{C}_{29} \mathrm{H}_{36} \mathrm{NO}_{5}, 478.2591$.

\subsection{3. (14ß)-(8'-Quinolinoxy)-9-dehydro-17-hydro-19-acetoxy-andrographolide (ZAF-46)}

To the solution of compound $8(0.50 \mathrm{~g}, 1.05 \mathrm{mmol})$ in dichloromethane $(10 \mathrm{~mL})$ and triethylamine $(0.36 \mathrm{~mL}, 2.62 \mathrm{mmol})$, acetyl chloride $(0.15 \mathrm{~mL}, 2.09 \mathrm{mmol})$ was added dropwise under ice-water bath. The reaction was complete in $3 \mathrm{~h}$ by TLC monitoring. The reaction solvent was evaporated, the residue was dissolved and extracted with ethyl acetate, washed twice with saturated aqueous sodium chloride solution, and the organic phase was dried over anhydrous $\mathrm{Na}_{2} \mathrm{SO}_{4}$. The organic phase was evaporated to dryness, and column chromatography was performed to afford ZAF-46: 60.3\% yield; white solid; m.p. 83.1-84.9 ${ }^{\circ} \mathrm{C} ;{ }^{1} \mathrm{H}$ NMR (400 MHz, DMSO- $\left.d_{6}\right) \delta 8.89(\mathrm{dd}, J=4.2,1.7 \mathrm{~Hz}, 1 \mathrm{H}), 8.39$ (dd, $J=8.4,1.7 \mathrm{~Hz}, 1 \mathrm{H}), 7.69(\mathrm{dd}, J=8.3,1.2 \mathrm{~Hz}, 1 \mathrm{H}), 7.62-7.49(\mathrm{~m}, 2 \mathrm{H}), 7.31(\mathrm{dd}, J=7.7,1.2 \mathrm{~Hz}$, $1 \mathrm{H}), 6.72(\mathrm{~s}, 1 \mathrm{H}), 6.13(\mathrm{~d}, J=5.3 \mathrm{~Hz}, 1 \mathrm{H}), 4.76(\mathrm{dd}, J=10.7,5.5 \mathrm{~Hz}, 1 \mathrm{H}), 4.69$ (d, $J=4.6 \mathrm{~Hz}$, $1 \mathrm{H}), 4.52(\mathrm{dd}, J=10.8,1.6 \mathrm{~Hz}, 1 \mathrm{H}), 4.11-3.99(\mathrm{~m}, 2 \mathrm{H}), 3.13(\mathrm{dt}, J=10.2,4.9 \mathrm{~Hz}, 1 \mathrm{H}), 2.89$ $(\mathrm{dd}, J=17.9,7.3 \mathrm{~Hz}, 1 \mathrm{H}), 2.77(\mathrm{dd}, J=18.0,6.0 \mathrm{~Hz}, 1 \mathrm{H}), 1.96(\mathrm{~s}, 3 \mathrm{H}), 1.91(\mathrm{~d}, J=5.2 \mathrm{~Hz}$, 2H), $1.72(\mathrm{~d}, J=12.6 \mathrm{~Hz}, 2 \mathrm{H}), 1.58-1.49(\mathrm{~m}, 2 \mathrm{H}), 1.45(\mathrm{~s}, 4 \mathrm{H}), 1.18(\mathrm{t}, J=7.1 \mathrm{~Hz}, 1 \mathrm{H}), 1.10(\mathrm{~d}$, $J=12.5 \mathrm{~Hz}, 1 \mathrm{H}), 1.03$ (s, 3H), 0.69 (s, 3H); ${ }^{13} \mathrm{C} \mathrm{NMR}(101 \mathrm{MHz}$, Chloroform-d) $\delta 171.1,169.9$, $152.4,151.0,149.6,141.4,136.2,135.9,129.9,129.6,126.6,124.6,122.8,121.9,115.8,78.8,74.1$, $71.4,65.4,51.9,42.1,38.6,34.9,34.4,28.5,27.6,22.4,21.1,19.8,19.4,19.3$; HRMS (ESI) $m / z$ $520.2693[\mathrm{M}+\mathrm{H}]^{+}$, calculated for $\mathrm{C}_{31} \mathrm{H}_{38} \mathrm{NO}_{6}, 520.2693$.

4.1.4. (14ß)-(8'-Quinolinoxy)-3-ketone-9-dehydro-17-hydro-19-acetoxy-andro grapholide (ZAF-47)

The solution of compound ZAF-46 $(0.30 \mathrm{~g}, 0.58 \mathrm{mmol})$ in anhydrous dichloromethane $(10.0 \mathrm{~mL})$ was treated with Dess Martin Periodinane (DMP) $(0.49 \mathrm{~g}, 1.15 \mathrm{mmol})$ for about $1 \mathrm{~h}$ by TLC monitoring in that the reaction was complete. The residue was dissolved and extracted with ethyl acetate, and then washed with sodium thiosulfate and saturated aqueous sodium chloride solution once, and the organic phase was dried over anhydrous $\mathrm{Na}_{2} \mathrm{SO}_{4}$. The organic phase was evaporated to dryness, and purification was conducted by silica gel column chromatography to provide ZAF-47: 75.8\% yield; white solid; m.p. 144.5-147.3 ${ }^{\circ} \mathrm{C} ;{ }^{1} \mathrm{H}$ NMR $\left(400 \mathrm{MHz}, \mathrm{DMSO}-\mathrm{d}_{6}\right) \delta 8.90(\mathrm{~d}, J=4.0 \mathrm{~Hz}, 1 \mathrm{H}), 8.39(\mathrm{~d}, J=8.3 \mathrm{~Hz}$, $1 \mathrm{H}), 7.69(\mathrm{~d}, J=8.2 \mathrm{~Hz}, 1 \mathrm{H}), 7.64-7.52(\mathrm{~m}, 2 \mathrm{H}), 7.32(\mathrm{~d}, J=7.7 \mathrm{~Hz}, 1 \mathrm{H}), 6.73(\mathrm{~s}, 1 \mathrm{H}), 6.14(\mathrm{~s}$, $1 \mathrm{H}), 4.77(\mathrm{dd}, J=10.9,5.6 \mathrm{~Hz}, 1 \mathrm{H}), 4.47(\mathrm{dd}, J=38.4,11.0 \mathrm{~Hz}, 2 \mathrm{H}), 3.91(\mathrm{~d}, J=11.4 \mathrm{~Hz}, 1 \mathrm{H})$, $2.97(\mathrm{t}, J=8.6 \mathrm{~Hz}, 2 \mathrm{H}), 2.64(\mathrm{~d}, J=31.9 \mathrm{~Hz}, 1 \mathrm{H}), 2.31(\mathrm{~s}, 1 \mathrm{H}), 2.05(\mathrm{~s}, 3 \mathrm{H}), 1.94(\mathrm{~s}, 3 \mathrm{H})$, $1.70(\mathrm{~s}, 2 \mathrm{H}), 1.52(\mathrm{~s}, 3 \mathrm{H}), 1.45(\mathrm{~s}, 1 \mathrm{H}), 1.07(\mathrm{~s}, 3 \mathrm{H}), 0.91(\mathrm{~s}, 3 \mathrm{H}), 0.85(\mathrm{~d}, J=7.6 \mathrm{~Hz}, 1 \mathrm{H})$; ${ }^{13} \mathrm{C}$ NMR (101 MHz, Chloroform-d) $\delta 213.1,170.9,169.7,152.4,150.6,149.6,141.3,136.3$, $134.9,130.1,130.0,126.6,124.8,122.8,121.9,115.5,73.9,71.3,65.8,52.8,51.1,38.3,35.6,34.9$, 33.8, 28.5, 21.4, 20.9, 19.8, 19.7, 19.5; HRMS (ESI) $m / z 518.2537[\mathrm{M}+\mathrm{H}]^{+}$, calculated for $\mathrm{C}_{31} \mathrm{H}_{36} \mathrm{NO}_{6}, 518.2537$.

\subsection{Cells and Viruses}

This study used the following cells: African green monkey kidney cells (Vero) (ATCC CCL-81) and human muscle rhabdomyosarcoma cells (RD) (ATCC CCL-136). Both cell lines were maintained in Dulbecco's Modified Eagle's Medium (DMEM) (Sigma-Aldrich, St. Louis, MO, USA), containing 10\% heat-inactivated fetal calf serum (HI-FCS) and $2 \mathrm{~g}$ of sodium hydrogen carbonate, at $37^{\circ} \mathrm{C}$ with $5 \% \mathrm{CO}_{2}$. This study used the following viruses: EV-A71 strain 41 (Accession no. AF316321.2); Coxsackievirus A6 (CV-A6) (Accession 
No. KC866983.1); Coxsackievirus A24 (CV-A24) (Accession No. KF725085.1); Echovirus 7 strain Wallace (Echo7) (Accession no. AF465516); Enterovirus D68 (EV-D68) (Accession No. KM851231); Coxsackievirus A16 (CV-A16) (Accession No. U05876); and Coxsackievirus B5 (CV-B5) (Accession No. JX843811.1). All enteroviruses except EV-D68 $\left(33^{\circ} \mathrm{C}\right)$ were propagated in $\mathrm{RD}$ cells at $37{ }^{\circ} \mathrm{C}$ with $5 \% \mathrm{CO}_{2}$ with reduced serum DMEM (2\% HI-FCS).

\subsection{Compound Library}

The compound library used in this study was made up of 344 chemically synthesized compounds analogous to andrographolide. A total of 100\% DMSO was used to dissolve each compound to attain $10 \mathrm{mM}$ concentration. Compounds were diluted further in serum-free DMEM to attain $100 \mu \mathrm{M}$ concentration and kept at $-20{ }^{\circ} \mathrm{C}$ for storage and future use.

\subsection{Preliminary Screen}

Seeded 96-well plates (Corning Inc., Corning, NY, USA), with $2 \times 10^{4}$ RD cells per well, were incubated overnight at $37^{\circ} \mathrm{C}$ with $5 \% \mathrm{CO}_{2}$. The seeded cells were then infected with EV-A71 $(50 \mu \mathrm{L}$ per well, MOI $=1)$ for $1 \mathrm{~h}$ at $37^{\circ} \mathrm{C}$ with $5 \% \mathrm{CO}_{2}$. The EV-A71-infected cells were then treated with the compound library at a final concentration of $10 \mu \mathrm{M}$ for $12 \mathrm{~h}$ at $37^{\circ} \mathrm{C}$ with $5 \% \mathrm{CO}_{2}$. Treatment with $0.1 \%$ DMSO was used as vehicle control. Following treatment, cells were fixed with $100 \mu \mathrm{L}$ of methanol (Sinopharm Chemical, Shanghai, China) for $15 \mathrm{~min}$ at $-20^{\circ} \mathrm{C}$ and rinsed with $100 \mu \mathrm{L}$ of $1 x$ PBS for three times before performing indirect immunofluorescence assay (IFA). Anti-EV-A71 VP2 $1^{\circ}$ antibodies, MAB979 (Merck Millipore, Burlington, VT, USA), diluted 500-fold in PBS, was incubated with the fixed cells for $1 \mathrm{~h}$ at $37^{\circ} \mathrm{C}$. Cells were then rinsed thrice with PBS and incubated with anti-mouse FITC $2^{\circ}$ antibodies (Merck Millipore), diluted 200-fold in PBS, for $1 \mathrm{~h}$ at $37^{\circ} \mathrm{C}$. After which, the cells were rinsed thrice with PBS before staining with DAPI (Sigma-Aldrich) at room temperature for $15 \mathrm{~min}$. Cells were then rinsed thrice and preserved in $100 \mu \mathrm{L}$ of PBS before imaging with the Operetta High-Content Imaging System and the Harmony High-Content Imaging and Analysis Software (Perkin Elmer, Waltham, MA, USA). Images of stained cells were captured with the DAPI and FITC fluorescence filters, from a pre-determined central position of each well and processed with the Cell Profiler software [71]. The Cell Profiler software defined the total number of cells and the number of infected cells for each well by the number of fluorescent foci captured from the DAPI-stained nuclei and the FITC-stained EV-A71 respectively. The percentage infection (PI) for each well was calculated using the formula: Infected cell count $\times 100 \%$. The percentage inhibition for each well was calculated using the formula $\frac{\mathrm{PI}_{0}-\mathrm{PI}}{\mathrm{PI}_{0}} \times 100 \%$ where $\mathrm{PI}_{0}$ refers to the percentage infection of wells treated with the vehicle control while PI refers to the percentage infection of wells treated with the compounds. Compounds that exhibited an inhibition rate of $>50 \%$ and total cell count comparable to the vehicle control were identified as potential hits.

Before conducting the preliminary screen, the robustness of the preliminary screening assay was assessed with Z-factor. Firstly, 96-well plates, seeded with $2 \times 10^{4} \mathrm{RD}$ cells per well, were incubated overnight. $50 \mu \mathrm{L}$ of EV-A71 (MOI =1) was used to infect the first 48 wells while the remaining 48 wells were mock-infected with $50 \mu \mathrm{L}$ of reduced serum DMEM, for $1 \mathrm{~h}$ at $37^{\circ} \mathrm{C}$ with $5 \% \mathrm{CO}_{2}$. Following which, additional $50 \mu \mathrm{L}$ of reduced serum DMEM were added to all the wells for another $12 \mathrm{~h}$ at $37{ }^{\circ} \mathrm{C}$ with $5 \% \mathrm{CO}_{2}$ before proceeding to IFA. Percentage infection was derived from IFA images of the wells. Z-factor was then calculated with the following formula: $1-\frac{3\left(\sigma_{p}+\sigma_{n}\right)}{\left|\mu_{p}-\mu_{n}\right|}$ where $p$ and $n$ refer to the positive and negative controls, which refer to EV-A71 infected and mock-infected respectively and $\mu$ and $\sigma$ refer to the mean and standard deviation values of the percentage infection of all wells, either EV-A71-infected or mock-infected, respectively [42]. 


\subsection{Cell Viability Assay}

To determine the cytotoxicity profiles of the hits, cell viability assay was performed. Seeded 96-well plates, with $2 \times 10^{4}$ RD cells per well, were incubated overnight at $37^{\circ} \mathrm{C}$ with $5 \% \mathrm{CO}_{2}$. Different concentrations of drug hits, diluted by reduced serum DMEM, were used to treat the seeded cells for $12 \mathrm{~h}$ at $37^{\circ} \mathrm{C}$ with $5 \% \mathrm{CO}_{2}$. Reduced serum DMEM, was employed as the negative control and $0.1 \%$ DMSO as the vehicle control for this step. Subsequently, the supernatant was replaced with alamarBlue ${ }^{\mathrm{TM}}$ Cell Viability Reagent (Thermo Fisher Scientific, Waltham, MA, USA) $(100 \mu \mathrm{L})$, diluted 10-fold in reduced serum DMEM, and incubated for $3 \mathrm{~h}$ at $37{ }^{\circ} \mathrm{C}$ with $5 \% \mathrm{CO}_{2}$. Fluorescence intensity in each well was measured at $570 \mathrm{~nm}$ excitation wavelength and $600 \mathrm{~nm}$ emission wavelength in each well by the Infinite ${ }^{\mathrm{TM}} 200$ series microplate reader (Tecan, Männedorf, Switzerland) and normaliszd with the negative control to determine the relative cell viability.

\subsection{Post-Treatment Assay}

To determine the inhibitory profiles of the hits, post treatment assay was performed. Seeded 24-well plates, with $1.5 \times 10^{5} \mathrm{RD}$ cells per well, were incubated overnight at $37{ }^{\circ} \mathrm{C}$ with $5 \% \mathrm{CO}_{2}$. The seeded cells were infected with EV-A71 (100 $\mu \mathrm{L}$ per well, MOI = 1) for $1 \mathrm{~h}$ at $37^{\circ} \mathrm{C}$ with $5 \% \mathrm{CO}_{2}$ and then rinsed with $1 \mathrm{~mL}$ of PBS twice. Different concentrations of the hits were used to treat the infected cells for $12 \mathrm{~h}$ at $37{ }^{\circ} \mathrm{C}$ with $5 \% \mathrm{CO}_{2}$. At $12 \mathrm{hpi}$, the plates were frozen and thawed for 2 cycles $\left(-80^{\circ} \mathrm{C} ; 37^{\circ} \mathrm{C}\right)$ before collection of supernatants to measure the viral titres via viral plaque assay.

\subsection{Viral Plaque Assays}

Measurement of the viral titres from collected supernatants was derived from viral plaque assays. To do this, 24-well plates, seeded with $2.4 \times 10^{5} \mathrm{RD}$ cells per well, were used in plaque assays for EV-A71, EV-D68, Echo7, CV-A6, CV-A16 and CV-A24 while 24-well plates, seeded with $1.2 \times 10^{5}$ Vero cells per well, were used in plaque assays for CV-B5. Seeded cells were incubated overnight at $37{ }^{\circ} \mathrm{C}$ with $5 \% \mathrm{CO}_{2}$. Viral supernatants were diluted from $10^{-1}$ to $10^{-7}$ in reduced serum DMEM before infecting the cells with a volume of $100 \mu \mathrm{L}$ for $1 \mathrm{~h}$ at $37^{\circ} \mathrm{C}$ with $5 \% \mathrm{CO}_{2}\left(33^{\circ} \mathrm{C}\right.$ instead for EV-D68). Cells were rinsed twice with PBS before overlaying with $1 \mathrm{~mL}$ of reduced serum DMEM containing $0.5 \%$ agarose (Vivantis, Shah Alam, Malaysia). Cells infected with Echo7 supernatants were incubated for 2 days, cells infected with CV-A24 and CV-B5 supernatants were incubated for 3 days and cells infected with EV-A71, CV-A6, CV-A16 and EV-D68 supernatants were incubated for 4 days for the formation of plaques. Subsequently, the cells were fixed and stained overnight with $4 \%$ paraformaldehyde and 1\% crystal violet (Sigma-Aldrich). Subsequent formation of viral plaques was counted manually to quantify the viral titre in $\mathrm{PFU} / \mathrm{mL}$

\subsection{Time-of-Addition and Time-of-Removal Assays}

Seeded 96-well plates, with $2 \times 10^{4} \mathrm{RD}$ cells per well, were incubated overnight at $37{ }^{\circ} \mathrm{C}$ with $5 \% \mathrm{CO}_{2}$ before subjecting to EV-A71 infection $(50 \mu \mathrm{L}$ per well, $\mathrm{MOI}=1)$ for $1 \mathrm{~h}$. The infected cells were rinsed twice with PBS. For TOA, cells were incubated with $100 \mu \mathrm{L}$ of reduced serum DMEM before replacement with $100 \mu \mathrm{L}$ of $20 \mu \mathrm{M}$ ZAF-47 at various time-points of $0,0.5,1,2,4,6,8,10 \mathrm{hpi}$. For TOR, $100 \mu \mathrm{L}$ of $20 \mu \mathrm{M}$ ZAF-47 was added to each well, then at similar time-points of $0,0.5,1,2,4,6,8,10 \mathrm{hpi}$, replaced with $100 \mu \mathrm{L}$ of reduced serum DMEM. The plates were frozen down at $12 \mathrm{hpi}$ for viral titre quantification using viral plaque assay.

\subsection{Pre-Treatment Assay}

Seeded 24-well plates, with $1.5 \times 10^{5} \mathrm{RD}$ cells per well, were incubated overnight at $37{ }^{\circ} \mathrm{C}$ with $5 \% \mathrm{CO}_{2}$. Cells were treated with $0.1 \%$ DMSO or varying concentrations of ZAF-47 for $2 \mathrm{~h}$ at $37{ }^{\circ} \mathrm{C}$ with $5 \% \mathrm{CO}_{2}$. Treated cells were then rinsed with PBS twice before subjecting to EV-A71 infection $(100 \mu \mathrm{L}$ per well, MOI $=1)$ for $1 \mathrm{~h}$. The infected cells were then rinsed twice with PBS before addition on $1 \mathrm{~mL}$ of reduced serum DMEM to each well 
and further incubated for $12 \mathrm{~h}$ at $37{ }^{\circ} \mathrm{C}$ with $5 \% \mathrm{CO}_{2}$. The plates were frozen down at $12 \mathrm{hpi}$ for viral titre quantification using viral plaque assay.

\subsection{Co-Treatment Assay}

Seeded 24-well plates, with $1.5 \times 10^{5} \mathrm{RD}$ cells per well, were incubated overnight at $37{ }^{\circ} \mathrm{C}$ with $5 \% \mathrm{CO}_{2}$. EV-A71 virions were incubated with $20 \mu \mathrm{M}$ of ZAF-47 or $0.1 \%$ DMSO in 1:1 ratio for $30 \mathrm{~min}$ at $37^{\circ} \mathrm{C}$ before filtration using a 100,000-molecular-weight centrifugal filter unit (Sartorius) for $5 \mathrm{~min}$ at $1,500 \mathrm{xg}$ and $4{ }^{\circ} \mathrm{C}$ to eliminate unbound molecules. The treated virions were further washed with PBS and filtered again before resuspension in reduced serum DMEM (assuming no loss of virions). The seeded cells were infected with the treated virions $(100 \mu \mathrm{L}$ per well, $\mathrm{MOI}=1)$ for $1 \mathrm{~h}$ at $37{ }^{\circ} \mathrm{C}$ with $5 \% \mathrm{CO}_{2}$, rinsed with $1 \mathrm{~mL}$ of PBS twice and incubated further for $12 \mathrm{~h}$ at $37{ }^{\circ} \mathrm{C}$ with $5 \% \mathrm{CO}_{2}$ after the addition of $1 \mathrm{~mL}$ of reduced serum DMEM. The plates were frozen down at $12 \mathrm{hpi}$ for viral titre quantification using viral plaque assay.

\subsection{Entry Bypass Assay}

Seeded 24-well plates, with $1.5 \times 10^{5} \mathrm{RD}$ cells per well, were incubated overnight at $37{ }^{\circ} \mathrm{C}$ with $5 \% \mathrm{CO}_{2}$. QIAamp Viral RNA Mini Kit (QIAGEN, Hilden, Germany) was used to extract the EV-A71 viral RNA. In summary, the virions were lysed with viral lysis buffer before precipitating nucleic acids with $100 \%$ ethanol for spin-column based extraction. Serum-free DMEM was used to dilute EV-A71 RNA (500 ng) and DharmaFECT 1 transfection reagent $(1 \mu \mathrm{L})$ (Thermo Fisher Scientific) separately to a final volume of $50 \mu \mathrm{L}$ before combining them to form transfection complexes. After 20 min of complexing, the seeded cells were transfected with $100 \mu \mathrm{L}$ of the EV-A71 RNA-DharmaFECT 1 transfection complexes for $1 \mathrm{~h}$. After which, $400 \mu \mathrm{L}$ of diluted ZAF-47 or DMSO were added and the cells were further incubated for $12 \mathrm{~h}$ at $37^{\circ} \mathrm{C}$ with $5 \% \mathrm{CO}_{2}$. The plates were frozen down at $12 \mathrm{hpi}$ for viral titre quantification using viral plaque assay.

\subsection{SDS-PAGE and Western Blot}

Seeded 24-well plates, with $1.5 \times 10^{5} \mathrm{RD}$ cells per well, were incubated overnight at $37{ }^{\circ} \mathrm{C}$ with $5 \% \mathrm{CO}_{2}$. After which, the cells were subjected to EV-A71 infection $(100 \mu \mathrm{L}$ per well, $\mathrm{MOI}=1$ ) for $1 \mathrm{~h}$. Reduced serum DMEM was used for mock-infection. The infected cells were then rinsed with PBS twice before treatment with $0.1 \%$ DMSO or ZAF-47 at various concentrations for $6 \mathrm{~h}$ at $37^{\circ} \mathrm{C}$ with $5 \% \mathrm{CO}_{2}$. After $6 \mathrm{~h}$ of drug treatment, cells were lysed with $100 \mu \mathrm{L}$ of $1 x$ Laemmli buffer and cell lysate was stored at $-80^{\circ} \mathrm{C}$.

The cell lysate samples were subsequently boiled for $10 \mathrm{~min}$ at $100{ }^{\circ} \mathrm{C}$ and loaded on to a $10 \%$ acrylamide gel. SDS-PAGE was run for $2.5 \mathrm{~h}$ at $100 \mathrm{~V}$ to separate the proteins. Bio Basic 10-250 kDa Protein Ladder BZ0011G (Bio Basic, Markham, Canada) was also loaded as a molecular-weight size marker. The separated proteins within the gel were transferred to a polyvinylidene difluoride (PVDF) membrane that was previously activated with methanol, using the Trans-Blot Turbo system (Bio-Rad) for 10 min at $1.3 \mathrm{~A}$. Following which, bovine serum albumin (BSA) (Sigma Aldrich) that was dissolved to $2 \%$ concentration in Tris-buffered saline-Tween 20 (TBST) was used to block the PVDF membrane for $30 \mathrm{~min}$. Mouse anti-EV-A71 VP2 $1^{\circ}$ antibodies, MAB979, was diluted in 2\% BSA by 10,000-fold before incubating with the membrane overnight at $4{ }^{\circ} \mathrm{C}$. TBST was used to wash the membrane thrice, 5 min each wash, before $1 \mathrm{~h}$ incubation at room temperature with horseradish peroxidase (HRP) conjugated goat anti-mouse IgG $2^{\circ}$ antibodies antibody (Thermo Fisher Scientific) that was diluted in $\%$ BSA by 100,000-folds. After, the membrane was washed thrice with TBST before immersing in Immobilon Western Chemiluminescent HRP substrate (Merck Millipore) for $3 \mathrm{~min}$ for detection of protein bands with the C-DiGit Chemiluminescence Western Blot Scanner (LI-COR, Lincoln, NE, USA).

Restore PLUS stripping buffer (Thermo Fisher Scientific) was used to dislodge the antibodies bound to the membrane to re-probe the membrane for $\beta$-actin so as to serve as loading control. Similarly, blocking of membrane was performed first before incuba- 
tion with diluted mouse anti- $\beta$-actin $1^{\circ}$ antibodies (Merck Millipore) and diluted HRPconjugated goat anti-mouse IgG $2^{\circ}$ antibodies (Thermo Fisher Scientific) for $45 \mathrm{~min}$ at room temperature. Both antibodies were diluted by 10,000 fold in $2 \%$ BSA. Finally, TBST was used to wash the membrane before chemiluminescent detection of protein bands.

\subsection{Nano-Luciferase Reporter Assay}

Seeded 96-well plates, with $2 \times 10^{4}$ RD cells per well, were incubated overnight at $37{ }^{\circ} \mathrm{C}$ with $5 \% \mathrm{CO}_{2}$. As described in our previous work [48], EV-A71 RNA replicons that were either replication-competent or replication-defective was used to transfect the seeded cells for $4 \mathrm{~h}$ at $37{ }^{\circ} \mathrm{C}$ with $5 \% \mathrm{CO}_{2}$. The transfection mixture per well was prepared as followed: EV-A71 replicon (100 ng); DharmaFECT 1 transfection reagent $(0.2 \mu \mathrm{L})$ and serum-free DMEM $(0.2 \mu \mathrm{L})$ for complexing before topping up with DMEM; $10 \% \mathrm{HI}-$ FCS $(80 \mu \mathrm{L})$. After transfection, cells were washed and treated with $0.1 \%$ DMSO, series of ZAF-47 concentrations, $1 \mathrm{mM} \mathrm{GuHCl}$ or $10 \mu \mathrm{g} / \mathrm{mL} \mathrm{CHX}$ for $12 \mathrm{~h}$ at $37{ }^{\circ} \mathrm{C}$ with $5 \%$ $\mathrm{CO}_{2}$. Nano-Glo kit (Promega, Madison, WI, USA) was used for luciferase detection after $12 \mathrm{~h}$ incubation.

\subsection{Bicistronic Luciferase Reporter Assay}

Seeded 96-well white plates (Corning), with $2 \times 10^{4}$ RD cells per well, were incubated overnight at $37{ }^{\circ} \mathrm{C}$ with $5 \% \mathrm{CO}_{2}$. After which, a bicstronic luciferase reporter construct was used to transfect the cells, as described in our previous work [52], for $12 \mathrm{~h}$ at $37{ }^{\circ} \mathrm{C}$ with $5 \% \mathrm{CO}_{2}$. The transfection mixture per well was prepared as followed: bicistronic construct $(200 \mathrm{ng})$, jetPRIME transfection reagent $(0.4 \mu \mathrm{L})$ (Polypus transfection, IllkirchGraffenstaden, France) and jetPRIME buffer $(9.6 \mu \mathrm{L})$ for complexing before topping up with reduced serum DMEM $(90 \mu \mathrm{L})$. After transfection, the cells were treated with $0.1 \%$ DMSO, series of ZAF-47 concentrations or $25 \mu \mathrm{M}$ of apigenin for $12 \mathrm{~h}$ at $37{ }^{\circ} \mathrm{C}$ with $5 \%$ $\mathrm{CO}_{2}$. Dual-Glo Luciferase Assay System (Promega) was used for luciferase detection after $12 \mathrm{~h}$ incubation.

\subsection{Generation of Resistant Mutant}

Seeded 24-well plates, with $1.5 \times 10^{5} \mathrm{RD}$ cells per well, were incubated overnight at $37{ }^{\circ} \mathrm{C}$ with $5 \% \mathrm{CO}_{2}$. After which, the cells were subjected to EV-A71 infection $(200 \mu \mathrm{L}$ per well, $\mathrm{MOI}=1$ ) for $1 \mathrm{~h}$ before treatment with $800 \mu \mathrm{L}$ of ZAF-47 at final concentration of $10 \mu \mathrm{M}$ for $12 \mathrm{~h}$ at $37{ }^{\circ} \mathrm{C}$ with $5 \% \mathrm{CO}_{2}$. Treatment with reduced serum DMEM and $0.1 \%$ DMSO functioned as negative and vehicle controls respectively. Upon $12 \mathrm{hpi}$, the supernatant was collected for viral plaque assay as well as to infect $(200 \mu \mathrm{L})$ another seeded plate. This process was repeated until the viral titre for ZAF-47 treated was comparable to the controls which may indicate generation of resistant mutants.

\subsection{Antiviral Spectrum of ZAF-47}

Post-treatment assays with ZAF-47 were performed against other Enteroviruses (CVA6, CV-A24, CVB-5, EV-D68, CV-A16 and Echo7) to investigate for antiviral activity. Virus infections were carried out at MOI $=1$. ZAF-47 treatment was performed for $12 \mathrm{~h}$ for all enteroviruses except for CV-A16 and CV-A4 (16 h and $4 \mathrm{~d}$ respectively). Cell viability assay was carried out to identify the low cytotoxic concentrations for post-treatment assay on enteroviruses with different incubation times (CV-A16 and CV-A6).

\subsection{Statistical Analysis}

Data assessment for statistical significance was performed with one-way analysis of variance (ANOVA) was performed followed by a Dunnett's post hoc test. Samples that were statistically different from the control had $p$-values $<0.05,0.01$ and 0.001 . Two-tailed students' T-test was performed to compare two samples. 


\section{Conclusions}

In conclusion, using an immunofluorescence-based phenotypic screen, we identified novel andrographolide derivatives as EV-A71 inhibitors. Among these hits, ZAF-47, a quinolinoxy-andrographolide, was discovered as an EV-A71 RNA replication-specific inhibitor. ZAF-47 was also effective against other enteroviruses, suggesting a broad-spectrum anti-enterovirus capability that would be very useful in developing antiviral treatment against HFMD.

Author Contributions: Conceptualization, J.J.H.C. and G.-C.Z.; data curation, J.J.H.C. G.-C.Z., J.K.T., R.C., R.C.H.L., F.L. and K.D.; formal analysis, J.J.H.C. G.-C.Z., J.K.T. and R.C.; funding acquisition, J.J.H.C. and G.-C.Z.; project administration, J.J.H.C. and G.-C.Z.; supervision, J.J.H.C. and G.-C.Z; investigation, J.K.T., R.C., R.C.H.L. and K.D.; writing-original draft, J.K.T. and R.C.; writing-review and editing, J.J.H.C. and G.-C.Z.; resources, J.J.H.C. and G.-C.Z.; methodology, J.K.T. and R.C.; validation, J.K.T. and R.C.; software, J.K.T., R.C., R.C.H.L., F.L. and K.D. All authors have read and agreed to the published version of the manuscript.

Funding: This research was partially funded by the National Natural Science Foundation of China to G.-C.Z. (30973621 and U0632001), Ministry of Education, Singapore to J.J.H.C. (MOE2017-T2-2-014) and NUHSRO/2020/050/RO5+5/NUHS-COVID/4 NUHS Seed Grant to J.J.H.C.

Institutional Review Board Statement: Not applicable.

Informed Consent Statement: Not applicable.

Data Availability Statement: The data are contained within the article.

Conflicts of Interest: The authors declare no conflict of interest.

\section{References}

1. Patil, R.; Jain, V. Andrographolide: A Review of Analytical Methods. J. Chromatogr. Sci. 2021, 59, 191-203. [CrossRef] [PubMed]

2. Dai, Y.; Chen, S.-R.; Chai, L.; Zhao, J.; Wang, Y.; Wang, Y. Overview of Pharmacological Activities of Andrographis Paniculata and Its Major Compound Andrographolide. Crit. Rev. Food Sci. Nutr. 2019, 59, S17-S29. [CrossRef] [PubMed]

3. Kumar, G.; Singh, D.; Tali, J.A.; Dheer, D.; Shankar, R. Andrographolide: Chemical Modification and Its Effect on Biological Activities. Bioorganic Chem. 2020, 95, 103511. [CrossRef]

4. Jiang, M.; Sheng, F.; Zhang, Z.; Ma, X.; Gao, T.; Fu, C.; Li, P. Andrographis Paniculata (Burm. f.) Nees and Its Major Constituent Andrographolide as Potential Antiviral Agents. J. Ethnopharmacol. 2021, 272, 113954. [CrossRef]

5. Wintachai, P.; Kaur, P.; Lee, R.C.H.; Ramphan, S.; Kuadkitkan, A.; Wikan, N.; Ubol, S.; Roytrakul, S.; Chu, J.J.H.; Smith, D.R. Activity of Andrographolide against Chikungunya Virus Infection. Sci. Rep. 2015, 5, 14179. [CrossRef]

6. Kaushik, S.; Dar, L.; Kaushik, S.; Yadav, J.P. Identification and Characterization of New Potent Inhibitors of Dengue Virus NS5 Proteinase from Andrographis Paniculata Supercritical Extracts on in Animal Cell Culture and in Silico Approaches. J. Ethnopharmacol. 2021, 267, 113541. [CrossRef]

7. Panraksa, P.; Ramphan, S.; Khongwichit, S.; Smith, D.R. Activity of Andrographolide against Dengue Virus. Antivir. Res. 2017, 139, 69-78. [CrossRef]

8. $\quad$ Lin, T.-P.; Chen, S.-Y.; Duh, P.-D.; Chang, L.-K.; Liu, Y.-N. Inhibition of the Epstein-Barr Virus Lytic Cycle by Andrographolide. Biol. Pharm. Bull. 2008, 31, 2018-2023. [CrossRef] [PubMed]

9. Yu, B.; Dai, C.; Jiang, Z.; Li, E.; Chen, C.; Wu, X.; Chen, J.; Liu, Q.; Zhao, C.; He, J.; et al. Andrographolide as an Anti-H1N1 Drug and the Mechanism Related to Retinoic Acid-Inducible Gene-I-like Receptors Signaling Pathway. Chin. J. Integr. Med. 2014, 20, 540-545. [CrossRef]

10. Chen, H.; Ma, Y.-B.; Huang, X.-Y.; Geng, C.-A.; Zhao, Y.; Wang, L.-J.; Guo, R.-H.; Liang, W.-J.; Zhang, X.-M.; Chen, J.-J. Synthesis, Structure-Activity Relationships and Biological Evaluation of Dehydroandrographolide and Andrographolide Derivatives as Novel Anti-Hepatitis B Virus Agents. Bioorganic Med. Chem. Lett. 2014, 24, 2353-2359. [CrossRef]

11. Lee, J.-C.; Tseng, C.-K.; Young, K.-C.; Sun, H.-Y.; Wang, S.-W.; Chen, W.-C.; Lin, C.-K.; Wu, Y.-H. Andrographolide Exerts Anti-Hepatitis C Virus Activity by up-Regulating Haeme Oxygenase-1 via the P38 MAPK/Nrf2 Pathway in Human Hepatoma Cells. Br. J. Pharmacol. 2014, 171, 237-252. [CrossRef]

12. Uttekar, M.M.; Das, T.; Pawar, R.S.; Bhandari, B.; Menon, V.; Nutan; Gupta, S.K.; Bhat, S.V. Anti-HIV Activity of Semisynthetic Derivatives of Andrographolide and Computational Study of HIV-1 Gp120 Protein Binding. Eur. J. Med. Chem. 2012, 56, 368-374. [CrossRef] [PubMed]

13. Niranjan Reddy, V.L.; Malla Reddy, S.; Ravikanth, V.; Krishnaiah, P.; Venkateshwar Goud, T.; Rao, T.P.; Siva Ram, T.; Gonnade, R.G.; Bhadbhade, M.; Venkateswarlu, Y. A New BIS-Andrographolide Ether from Andrographis Paniculata Nees and Evaluation of Anti-HIV Activity. Nat. Prod. Res. 2005, 19, 223-230. [CrossRef] 
14. Seubsasana, S.; Pientong, C.; Ekalaksananan, T.; Thongchai, S.; Aromdee, C. A Potential Andrographolide Analogue against the Replication of Herpes Simplex Virus Type 1 in Vero Cells. Med. Chem. 2011, 7, 237-244. [CrossRef]

15. Wiart, C.; Kumar, K.; Yusof, M.Y.; Hamimah, H.; Fauzi, Z.M.; Sulaiman, M. Antiviral Properties of Ent-Labdene Diterpenes of Andrographis Paniculata Nees, Inhibitors of Herpes Simplex Virus Type 1. Phytother. Res. 2005, 19, 1069-1070. [CrossRef] [PubMed]

16. Sa-ngiamsuntorn, K.; Suksatu, A.; Pewkliang, Y.; Thongsri, P.; Kanjanasirirat, P.; Manopwisedjaroen, S.; Charoensutthivarakul, S.; Wongtrakoongate, P.; Pitiporn, S.; Chaopreecha, J.; et al. Anti-SARS-CoV-2 Activity of Andrographis Paniculata Extract and Its Major Component Andrographolide in Human Lung Epithelial Cells and Cytotoxicity Evaluation in Major Organ Cell Representatives. J. Nat. Prod. 2021, 84, 1261-1270. [CrossRef]

17. Shi, T.-H.; Huang, Y.-L.; Chen, C.-C.; Pi, W.-C.; Hsu, Y.-L.; Lo, L.-C.; Chen, W.-Y.; Fu, S.-L.; Lin, C.-H. Andrographolide and Its Fluorescent Derivative Inhibit the Main Proteases of 2019-NCoV and SARS-CoV through Covalent Linkage. Biochem. Biophys. Res. Commun. 2020, 533, 467-473. [CrossRef]

18. Wang, D.; Guo, H.; Chang, J.; Wang, D.; Liu, B.; Gao, P.; Wei, W. Andrographolide Prevents EV-D68 Replication by Inhibiting the Acidification of Virus-Containing Endocytic Vesicles. Front. Microbiol. 2018, 9, 2407. [CrossRef] [PubMed]

19. Schmidt, N.J.; Lennette, E.H.; Ho, H.H. An Apparently New Enterovirus Isolated from Patients with Disease of the Central Nervous System. J. Infect. Dis. 1974, 129, 304-309. [CrossRef]

20. Kennett, M.L.; Birch, C.J.; Lewis, F.A.; Yung, A.P.; Locarnini, S.A.; Gust, I.D. Enterovirus Type 71 Infection in Melbourne. Bull. World Health Organ. 1974, 51, 609-615. [PubMed]

21. Chumakov, M.; Voroshilova, M.; Shindarov, L.; Lavrova, I.; Gracheva, L.; Koroleva, G.; Vasilenko, S.; Brodvarova, I.; Nikolova, M.; Gyurova, S.; et al. Enterovirus 71 Isolated from Cases of Epidemic Poliomyelitis-like Disease in Bulgaria. Arch. Virol. 1979, 60, 329-340. [CrossRef]

22. Tagaya, I.; Takayama, R.; Hagiwara, A. A Large-Scale Epidemic of Hand, Foot and Mouth Disease Associated with Enterovirus 71 Infection in Japan in 1978. Jpn. J. Med. Sci. Biol. 1981, 34, 191-196. [CrossRef]

23. Nagy, G.; Takátsy, S.; Kukán, E.; Mihály, I.; Dömök, I. Virological Diagnosis of Enterovirus Type 71 Infections: Experiences Gained during an Epidemic of Acute CNS Diseases in Hungary in 1978. Arch. Virol. 1982, 71, 217-227. [CrossRef] [PubMed]

24. Chua, K.B.; Chua, B.H.; Lee, C.S.M.; Chem, Y.K.; Ismail, N.; Kiyu, A.; Kumarasamy, V. Genetic Diversity of Enterovirus 71 Isolated from Cases of Hand, Foot and Mouth Disease in the 1997, 2000 and 2005 Outbreaks, Peninsular Malaysia. Malays. J. Pathol. 2007, 29, 69-78. [PubMed]

25. Ho, M.; Chen, E.-R.; Hsu, K.-H.; Twu, S.-J.; Chen, K.-T.; Tsai, S.-F.; Wang, J.-R.; Shih, S.-R. An Epidemic of Enterovirus 71 Infection in Taiwan. N. Engl. J. Med. 1999, 341, 929-935. [CrossRef] [PubMed]

26. Huang, S.-W.; Hsu, Y.-W.; Smith, D.J.; Kiang, D.; Tsai, H.-P.; Lin, K.-H.; Wang, S.-M.; Liu, C.-C.; Su, I.-J.; Wang, J.-R. Reemergence of Enterovirus 71 in 2008 in Taiwan: Dynamics of Genetic and Antigenic Evolution from 1998 to 2008. J. Clin. Microbiol. 2009, 47, 3653-3662. [CrossRef] [PubMed]

27. Lin, K.-H.; Hwang, K.-P.; Ke, G.-M.; Wang, C.-F.; Ke, L.-Y.; Hsu, Y.-T.; Tung, Y.-C.; Chu, P.-Y.; Chen, B.-H.; Chen, H.-L.; et al. Evolution of EV71 Genogroup in Taiwan from 1998 to 2005: An Emerging of Subgenogroup C4 of EV71. J. Med. Virol. 2006, 78, 254-262. [CrossRef] [PubMed]

28. Lin, T.-Y.; Twu, S.-J.; Ho, M.-S.; Chang, L.-Y.; Lee, C.-Y. Enterovirus 71 Outbreaks, Taiwan: Occurrence and Recognition. Emerg. Infect. Dis. 2003, 9, 291-293. [CrossRef]

29. Hosoya, M.; Kawasaki, Y.; Sato, M.; Honzumi, K.; Kato, A.; Hiroshima, T.; Ishiko, H.; Suzuki, H. Genetic Diversity of Enterovirus 71 Associated with Hand, Foot and Mouth Disease Epidemics in Japan from 1983 to 2003. Pediatr. Infect. Dis. J. 2006, 25, 691-694. [CrossRef]

30. Wu, Y.; Yeo, A.; Phoon, M.C.; Tan, E.L.; Poh, C.L.; Quak, S.H.; Chow, V.T.K. The Largest Outbreak of Hand; Foot and Mouth Disease in Singapore in 2008: The Role of Enterovirus 71 and Coxsackievirus a Strains. Int. J. Infect. Dis. 2010, 14, e1076-e1081. [CrossRef]

31. Chong, C.Y.; Chan, K.P.; Shah, V.A.; Ng, W.Y.M.; Lau, G.; Teo, T.E.S.; Lai, S.H.; Ling, A.E. Hand, Foot and Mouth Disease in Singapore: A Comparison of Fatal and Non-Fatal Cases. Acta Paediatr. 2003, 92, 1163-1169. [CrossRef]

32. Yang, B.; Liu, F.; Liao, Q.; Wu, P.; Chang, Z.; Huang, J.; Long, L.; Luo, L.; Li, Y.; Leung, G.M.; et al. Epidemiology of Hand, Foot and Mouth Disease in China, 2008 to 2015 Prior to the Introduction of EV-A71 Vaccine. Eurosurveillance 2017, 22, 16-00824. [CrossRef]

33. Puenpa, J.; Wanlapakorn, N.; Vongpunsawad, S.; Poovorawan, Y. The History of Enterovirus A71 Outbreaks and Molecular Epidemiology in the Asia-Pacific Region. J. Biomed. Sci. 2019, 26, 75. [CrossRef]

34. Liu, M.Y.; Liu, W.; Luo, J.; Liu, Y.; Zhu, Y.; Berman, H.; Wu, J. Characterization of an Outbreak of Hand, Foot, and Mouth Disease in Nanchang, China in 2010. PLoS ONE 2011, 6, e25287. [CrossRef]

35. Messacar, K.; Burakoff, A.; Nix, W.A.; Rogers, S.; Oberste, M.S.; Gerber, S.I.; Spence-Davizon, E.; Herlihy, R.; Dominguez, S.R. Notes from the Field: Enterovirus A71 Neurologic Disease in Children-Colorado, 2018. MMWR Morb. Mortal. Wkly. Rep. 2018, 67, 1017-1018. [CrossRef]

36. Taravilla, C.N.; Pérez-Sebastián, I.; Salido, A.G.; Serrano, C.V.; Extremera, V.C.; Rodríguez, A.D.; Marín, L.L.; Sanz, M.A.; Traba, O.M.S.; González, A.S. Enterovirus A71 Infection and Neurologic Disease, Madrid, Spain, 2016. Emerg. Infect. Dis. 2019, 25, 25-32. [CrossRef] [PubMed] 
37. Antona, D.; Kossorotoff, M.; Schuffenecker, I.; Mirand, A.; Leruez-Ville, M.; Bassi, C.; Aubart, M.; Moulin, F.; Lévy-Bruhl, D.; Henquell, C.; et al. Severe Paediatric Conditions Linked with EV-A71 and EV-D68, France, May to October 2016. Eurosurveillance 2016, 21, 30402. [CrossRef]

38. Li, X.; Zhang, C.; Shi, Q.; Yang, T.; Zhu, Q.; Tian, Y.; Lu, C.; Zhang, Z.; Jiang, Z.; Zhou, H.; et al. Improving the Efficacy of Conventional Therapy by Adding Andrographolide Sulfonate in the Treatment of Severe Hand, Foot, and Mouth Disease: A Randomized Controlled Trial. Evid.-Based Complement. Altern. Med. 2013, 2013, 1-8. [CrossRef] [PubMed]

39. Zhang, G.; Hou, Y.; Li, Y.; He, L.; Tang, L.; Yang, T.; Zou, X.; Zhu, Q.; Yan, S.; Huang, B.; et al. Xiyanping Injection Therapy for Children with Mild Hand Foot and Mouth Disease: A Randomized Controlled Trial. J. Tradit. Chin. Med. 2017, 37, 397-403. [PubMed]

40. Li, M.; Yang, X.; Guan, C.; Wen, T.; Duan, Y.; Zhang, W.; Li, X.; Wang, Y.; Zhao, Z.; Liu, S. Andrographolide Sulfonate Reduces Mortality in Enterovirus 71 Infected Mice by Modulating Immunity. Int. Immunopharmacol. 2018, 55, 142-150. [CrossRef]

41. Min, N.; Leong, P.T.; Lee, R.C.H.; Khuan, J.S.E.; Chu, J.J.H. A Flavonoid Compound Library Screen Revealed Potent Antiviral Activity of Plant-Derived Flavonoids on Human Enterovirus A71 Replication. Antivir. Res. 2018, 150, 60-68. [CrossRef] [PubMed]

42. Zhang, J.-H.; Chung, T.D.Y.; Oldenburg, K.R. A Simple Statistical Parameter for Use in Evaluation and Validation of High Throughput Screening Assays. J. Biomol. Screen. 1999, 4, 67-73. [CrossRef] [PubMed]

43. Dai, K.; Tan, J.K.; Qian, W.; Lee, R.C.H.; Chu, J.J.H.; Zhou, G.-C. Discovery of 14S-(2'-Chloro-4'-Nitrophenoxy)-8R/S, 17-Epoxy Andrographolide as EV-A71 Infection Inhibitor. Biochem. Pharmacol. 2021, 194, 114820. [CrossRef]

44. Li, F.; Lee, E.M.; Sun, X.; Wang, D.; Tang, H.; Zhou, G.-C. Design, Synthesis and Discovery of Andrographolide Derivatives against Zika Virus Infection. Eur. J. Med. Chem. 2020, 187, 111925. [CrossRef] [PubMed]

45. Liu, Z.; Law, W.-K.; Wang, D.; Nie, X.; Sheng, D.; Song, G.; Guo, K.; Wei, P.; Ouyang, P.; Wong, C.-W.; et al. Synthesis and Discovery of Andrographolide Derivatives as Non-Steroidal Farnesoid X Receptor (FXR) Antagonists. RSC Adv. 2014, 4, 13533-13545. [CrossRef]

46. Dey, A.; Chen, R.; Li, F.; Maitra, S.; Hernandez, J.-F.; Zhou, G.-C.; Vincent, B. Synthesis and Characterization of Andrographolide Derivatives as Regulators of BAPP Processing in Human Cells. Molecules 2021, 26, 7660. [CrossRef] [PubMed]

47. Lu, J.; He, Y.Q.; Yi, L.N.; Zan, H.; Kung, H.F.; He, M.L. Viral Kinetics of Enterovirus 71 in Human Habdomyosarcoma Cells. World J. Gastroenterol. 2011, 17, 4135-4142. [CrossRef]

48. $\mathrm{Wu}, \mathrm{K} . X . ; \mathrm{Chu}$, J.J.-H. Antiviral Screen Identifies EV71 Inhibitors and Reveals Camptothecin-Target, DNA Topoisomerase 1 as a Novel EV71 Host Factor. Antivir. Res. 2017, 143, 122-133. [CrossRef]

49. Yuan, J.; Shen, L.; Wu, J.; Zou, X.; Gu, J.; Chen, J.; Mao, L. Enterovirus A71 Proteins: Structure and Function. Front. Microbiol. 2018, 9, 286. [CrossRef]

50. Murray, K.E.; Nibert, M.L. Guanidine Hydrochloride Inhibits Mammalian Orthoreovirus Growth by Reversibly Blocking the Synthesis of Double-Stranded RNA. J. Virol. 2007, 81, 4572-4584. [CrossRef]

51. Schneider-Poetsch, T.; Ju, J.; Eyler, D.E.; Dang, Y.; Bhat, S.; Merrick, W.C.; Green, R.; Shen, B.; Liu, J.O. Inhibition of Eukaryotic Translation Elongation by Cycloheximide and Lactimidomycin. Nat. Chem. Biol. 2010, 6, 209-217. [CrossRef]

52. Gunaseelan, S.; Wong, K.Z.; Min, N.; Sun, J.; Ismail, N.K.B.M.; Tan, Y.J.; Lee, R.C.H.; Chu, J.J.H. Prunin Suppresses Viral IRES Activity and Is a Potential Candidate for Treating Enterovirus A71 Infection. Sci. Transl. Med. 2019, 11, eaar5759. [CrossRef] [PubMed]

53. Lv, X.; Qiu, M.; Chen, D.; Zheng, N.; Jin, Y.; Wu, Z. Apigenin Inhibits Enterovirus 71 Replication through Suppressing Viral IRES Activity and Modulating Cellular JNK Pathway. Antivir. Res. 2014, 109, 30-41. [CrossRef] [PubMed]

54. Swinney, D.C. Phenotypic vs. Target-Based Drug Discovery for First-in-Class Medicines. Clin. Pharmacol. Ther. 2013, 93, $299-301$. [CrossRef] [PubMed]

55. Loureiro Damasceno, J.P.; Silva da Rosa, H.; Silva de Araújo, L.; Jacometti Cardoso Furtado, N.A. Andrographis Paniculata Formulations: Impact on Diterpene Lactone Oral Bioavailability. Eur. J. Drug Metab. Pharmacokinet. 2022, 47, 19-30. [CrossRef] [PubMed]

56. Xu, Y.; Wei, H.; Wang, J.; Wang, W.; Gao, J. Synthesis of Andrographolide Analogues and Their Neuroprotection and Neurite Outgrowth-Promoting Activities. Bioorganic Med. Chem. 2019, 27, 2209-2219. [CrossRef] [PubMed]

57. Gong, C.; Xu, C.; Ji, L.; Wang, Z. A Novel Semi-Synthetic Andrographolide Analogue A5 Inhibits Tumor Angiogenesis via Blocking the VEGFR2-P38/ERK1/2 Signal Pathway. Biosci. Trends 2013, 7, 230-236. [CrossRef]

58. Xiao, X.-W.; Fu, H.-Z.; Luo, Y.-H.; Wei, X.-Y. Potential Anti-Angiogenic Sulfates of Andrographolide. J. Asian Nat. Prod. Res. 2013, 15, 809-818. [CrossRef] [PubMed]

59. Wen, T.; Xu, W.; Liang, L.; Li, J.; Ding, X.; Chen, X.; Hu, J.; Lv, A.; Li, X. Clinical Efficacy of Andrographolide Sulfonate in the Treatment of Severe Hand, Foot, and Mouth Disease (HFMD) Is Dependent upon Inhibition of Neutrophil Activation. Phytother. Res. 2015, 29, 1161-1167. [CrossRef]

60. Delvecchio, R.; Higa, L.; Pezzuto, P.; Valadão, A.; Garcez, P.; Monteiro, F.; Loiola, E.; Dias, A.; Silva, F.; Aliota, M.; et al. Chloroquine, an Endocytosis Blocking Agent, Inhibits Zika Virus Infection in Different Cell Models. Viruses 2016, 8, 322. [CrossRef]

61. Kumar, A.; Liang, B.; Aarthy, M.; Singh, S.K.; Garg, N.; Mysorekar, I.U.; Giri, R. Hydroxychloroquine Inhibits Zika Virus NS2B-NS3 Protease. ACS Omega 2018, 3, 18132-18141. [CrossRef] 
62. Roldan, E.Q.; Biasiotto, G.; Magro, P.; Zanella, I. The Possible Mechanisms of Action of 4-Aminoquinolines (Chloroquine/Hydroxychloroquine) against SARS-Cov-2 Infection (COVID-19): A Role for Iron Homeostasis? Pharmacol. Res. 2020, 158, 104904. [CrossRef]

63. Biot, C.; Daher, W.; Chavain, N.; Fandeur, T.; Khalife, J.; Dive, D.; De Clercq, E. Design and Synthesis of Hydroxyferroquine Derivatives with Antimalarial and Antiviral Activities. J. Med. Chem. 2006, 49, 2845-2849. [CrossRef]

64. Vishvakarma, V.K.; Nand, B.; Kumar, V.; Kumari, K.; Bahadur, I.; Singh, P. Xanthene Based Hybrid Analogues to Inhibit Protease of Novel Corona Virus: Molecular Docking and ADMET Studies. Comput. Toxicol. 2020, 16, 100140. [CrossRef]

65. Li, F.; Li, X.-M.; Sheng, D.; Chen, S.-R.; Nie, X.; Liu, Z.; Wang, D.; Zhao, Q.; Wang, Y.; Wang, Y.; et al. Discovery and Preliminary SAR of 14-Aryloxy-Andrographolide Derivatives as Antibacterial Agents with Immunosuppressant Activity. RSC Adv. 2018 8, 9440-9456. [CrossRef]

66. Richter, S.; Parolin, C.; Palumbo, M.; Palu, G. Antiviral Properties of Quinolone-Based Drugs. Curr. Drug Target-Infect. Disord. 2004, 4, 111-116. [CrossRef]

67. Tran, Q.T.N.; Tan, W.S.D.; Wong, W.S.F.; Chai, C.L.L. Polypharmacology of Andrographolide: Beyond One Molecule One Target. Nat. Prod. Rep. 2021, 38, 682-692. [CrossRef] [PubMed]

68. Chang, C.-C.; Duann, Y.-F.; Yen, T.-L.; Chen, Y.-Y.; Jayakumar, T.; Ong, E.-T.; Sheu, J.-R. Andrographolide, a Novel NF-kB Inhibitor, Inhibits Vascular Smooth Muscle Cell Proliferation and Cerebral Endothelial Cell Inflammation. Acta Cardiol. Sin. 2014, 30, 308-315. [PubMed]

69. Jin, Y.; Zhang, R.; Wu, W.; Duan, G. Antiviral and Inflammatory Cellular Signaling Associated with Enterovirus 71 Infection. Viruses 2018, 10, 155. [CrossRef] [PubMed]

70. Srikanth, L.; Sarma, P.V.G.K. Andrographolide Binds to Spike Glycoprotein and RNA-Dependent RNA Polymerase (NSP12) of SARS-CoV-2 by in Silico Approach: A Probable Molecule in the Development of Anti-Coronaviral Drug. J. Genet. Eng. Biotechnol. 2021, 19, 101. [CrossRef]

71. Carpenter, A.E.; Jones, T.R.; Lamprecht, M.R.; Clarke, C.; Kang, I.H.; Friman, O.; Guertin, D.A.; Chang, J.H.; Lindquist, R.A.; Moffat, J.; et al. CellProfiler: Image Analysis Software for Identifying and Quantifying Cell Phenotypes. Genome Biol. 2006, 7, R100. [CrossRef] [PubMed] 